\title{
Mekân Dizimi ve Yol Bulma Metotları ile Yaya Hareketliliği ve Arazi Kullanımı İlişkisinin Kadıköy Tarihi Merkezi'nde İrdelenmesi
}

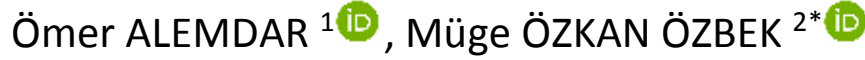 \\ ORCID 1: 0000-0003-2210-695X \\ ORCID 2: 0000-0002-7636-0438 \\ 1,2 Mimar Sinan Güzel Sanatlar Üniversitesi, Mimarlık Fakültesi, Şehir ve Bölge Planlama Bölümü, 34421, \\ istanbul, Türkiye. \\ Öz \\ *e-mail: muge.ozkan.ozbek@msgsu.edu.tr \\ Günümüzde kentlerin kimliklerini kaybetmesi, kentlerin strüktürünün, kentsel kullanımının, mimari çeşitliliğin, \\ tartışılmasını gerektirmiştir. Bu ilişkileri açıklamak amacıyla morfolojik bir metot olan Mekân Dizimi (Space \\ Syntax) yöntemi 1970'lerde Bill Hillier ve çalışma arkadaşları tarafından kentsel ve mimari ölçekte çalışmaları \\ araştırmak için geliştirilmiş bir yöntemdir. Bu yöntemle birlikte hareketlilik ve arazi kullanımı arasındaki ilişkiyi \\ mekânsal kalite ile birlikte değerlendirebilmek adına bir sağlama yapmak amacıyla "Yol Bulma" (Wayfinding) \\ yöntemi de kullanılmaktadır. Bu araştırmada çalışma alanı seçilen Kadıköy bölgesinde mekân dizimi ve yol bulma \\ metotları kullanılarak, analizler yapılmıştır. Kadıköy'de yayaların en fazla kullandıkları sokaklar her iki yöntemle \\ analiz edilerek kullanım nedenleri ve mekânların fiziksel özellikleri tartışılmıştır. Ayrıca Kadıköy'ün tarihsel \\ süreçteki morfolojik yapısının sentaktik incelemeleri de yapılarak güçlü aksların devamlılığı ya da değişim \\ nedenleri tartışılmıştır. Sonuçta; kentsel mekânın kullanıcıları, en çok tercih edilen, en uzun görüşe sahip, en \\ güvenli, mekânsal kalitesi en iyi olan ve kentin en fazla bütünleşmiş yolları kullandıkları tespit edilmiştir.
}

Anahtar Kelimeler: Kadıköy, mekân dizimi, yol bulma, yaya hareketliliği, kentsel morfoloji

\section{Examination of the Relationships between Pedestrian Mobility and Land Use with Space Syntax and Wayfinding Methods in Kadıköy Historical Center}

\begin{abstract}
Cities with identity issues, have required the discussion of the structure of cities, urban use and architectural diversity. Space Syntax as a morphologic method developed by Bill Hillier and his colleagues in the 1970's to analyze urban and architectural scale studies in order to explain their syntactic relationships. Along with this method, "Wayfinding" method is also used to make a check in order to evaluate the relationship between mobility and land use together with spatial quality. In this study, analyzes were carried out using the space syntax and route finding methods in the Kadıköy region. The streets mostly used by pedestrians in Kadıköy are analyzed and the results for the spaces are discussed. Syntactic examinations of the morphological structure of Kadıköy, from the historical process were also analyzed and the continuity of the strong axes or changes have been discussed. As a result; It has been determined that the users of the urban space use the most preferred roads with the longest view, the safest, with the best spatial quality and the most integrated streets of the city.
\end{abstract}

Keywords: Kadıköy, space syntax, wayfinding method, pedestrian mobility, urban morphology

1. Giriş

Atıf/Citation: Alemdar, Ö, Özkan Özbek, M. (2021). Mekân Dizimi ve Yol Bulma Metotları ile Yaya Hareketliliği ve Arazi Kullanımı İlişkisinin Kadıköy Tarihi Merkezi'nde İrdelenmesi. Journal of Architectural Sciences and Applications, 6 (1), 77-96. DOI: 10.30785/mbud.779991 
İstanbul, birçok uygarlığın ve farklı kültürlerin yaşadığı ve geliştiği metropollerin en önemlilerinden biridir. Anadolu yakasında bulunan Kadıköy ilçesi de İstanbul'un özellikle Anadolu yakası için bir ticaret, kültür ve ulaşım merkezidir. Aynı zamanda Kadıköy; Rasimpaşa (Yeldeğirmeni bölgesi) kentsel sit alanı, tescilli yapıları ve Tarihi Çarşısı (kentsel sit alanı) ile bir bütün olarak tarihsel dokuya sahip olan geleneksel bir yerleşim merkezidir.

Çalışmanın amacı; morfolojik bir yöntem olan "Mekân Dizimi" metodu ile Kadıköy tarihi merkezinin erişilebilirlik ve "Yol Bulma" analizlerinin yapılarak bölgedeki hareketliliği, dolayısıyla etkilediği arazi kullanım değerlerini ve yerin kalitesini ölçmektir. Ayrıca çalışmada, kentsel çevredeki sentaktik faktörleri araştırmak, anlamak ve bunları şehirdeki kentsel yerleşimin sınırlandırılmış bir bölümü için sentezleyerek yaşam ve mekân kalitesini ölçmek amaçlanmıştır. Çalışma sonucunda Kadıköy tarihi merkezine yönelik, alanın yaya hareketlilik dokusunun etkilerinin saptanması ve değerlendirilmesi mümkün olacaktır. Bu değerlendirmeler, mekânsal bir strateji üretmeyi amaçlayan çalışmalar için bir başlangıç aşaması niteliğini taşıyacaktır.

Mekânsal organizasyon ile hareket ve ikisi arasındaki ilişkinin belirlenmesi için çalışma alanı olan Kadıköy ilçesinde bir sınır belirlenmiştir. Bu sınırı belirleyen birtakım ögeler olmuştur. Bunlar su, otoyol, demiryolu ve TCDD'nin arazisidir. Çalışmada mekân dizimi ve yol bulma yöntemlerinin amaç ve analiz türleri örneklerle birlikte kavramsal açıklamalarıyla aktarımıştır. Kullanılacak metodun matematiği ve birimlerinden bahsedilerek çalışmanın daha anlaşıır olması amaçlanmıştır. Mekân dizimi ve yol bulma yöntemleri kullanılarak yapılan yaya hareketliliği çalışmalarından örnekler değerlendirilmiş ve bu değerlendirmeler çalışmanın kavramsal çerçevesinin oluşturulmasında katkı sağlamıştır. Kadıköy tarihi merkezinin tarihsel süreçteki fiziksel değişimi ve özellikleri 19.yy'dan günümüze kadar ki olan süreçte kent mekânının geçirdiği fiziksel değişim ile ele alınmıştır. Kentsel mekânının tarihsel süreçte yaşadığı olumsuzluklarla birbirinden nasıl koparıldığı irdelenmiş ve bu aşamada kentsel mekândaki hareket ve yaya dolaşımı kavramları tarihsel süreç çerçevesinde değerlendirilebilmiştir. Kadıköy tarihi merkezi üzerinde mekân dizimi ve yol bulma yöntemleri ile alan çalışmasına dair yapılmış olan rota çalışması ve diğer analizlerle birlikte yapılan analizler aktarılarak kullanılan iki yöntemin ortaya çıkardığı verilerin genel bir değerlendirmesi ve sentezi yapılmıştır.

\section{Materyal ve Yöntem}

Yöntemin kavramsal açıklamalarıyla anlatımlarının ardından, yöntem analizleri için, eski haritalar, hava fotoğrafları, Kadıköy'ün sayısal ortamdaki 2016 tarihli halihazır haritası kullanılmıştır. Mekân Dizimi yönteminin ana haritası olan aksiyel haritalar oluşturularak, bu çizimler Depthmap 0.35 adlı program kullanılarak "Aksiyel Analiz" ve "Segment Analizi" biçimleri kullanılmıştır.

Yol bulma analizini yapabilmek için ise öncelikle Kadıköy tarihi merkezinde beş adet nirengi noktası belirlenmiştir. Daha sonra "yönlendirilmiş arama" (directed search) olan bu yol bulma çalışması için seçilen nirengi noktalarından bir rota oluşturulmuştur. Aslında bir deney olan yol bulma çalışması kapsamında, görece önceden bölgeyi daha az deneyimlemiş farklı yaş ve cinsiyette olan 10 kişi belirlenmiş̧ir. Farklı zamanlarda her biriyle ayrı ayrı belirlenmiş aynı rota istikametinde dolaşılarak yol bulma çalışması tamamlanmıştır. Böylelikle belirlenmiş rota için farklı farklı 10 adet hareket ağı oluşturulmuştur.

Mekân dizim metodunun kurucularından olan Hillier'e (1987) göre mekân; kültürel ve sosyal yapılara göre formunu alan bir makine ve bu formlara eşlik eden tarafsı bir çerçevedir. Fiziksel çevrenin, toplumu oluşturma potansiyeli sınırlı da olsa etkisi kesindir. Mekân sürekli olarak başka mekânlara doğru akıp dönüşebilmektedir. Başka bir deyişle de kentlinin varoluşu için mekân algısını en genel anlamda biçimlendiren olgu mekânın yaşanılması ve duyumsanmasıdır (Kurtar, 2006). Bir yerleşmede yaşayan insanlar o yerleşmenin fiziki kurgusuna göre yaşam biçimlerini örgütlerler ve birbirleri aralarında da o mekânı kullanmada ortak bir dil yaratırlar. Sosyal ve kültürel yaşam şekillerine göre birtakım kentsel mekânsal ögeler yaratırlar ve mekân içinde şekillenen kenti ortaya çıkarırlar (Özkan Özbek, 2007). Kentsel mekân, yapıların oluşturduğu, tüm kentsel olayların ilişkilendirildiği ve tüm kentlinin algıladığı bir bütündür. Kentsel mekânı oluşturan temel ögeler; Düğüm noktaları (merkez ve alt merkezler), sınırlar, yollar, bölgeler, anıtsal ögeler olarak tanımlanmıştır (Lynch, 1960). Kentsel mekândaki kimliğin oluşmasında mekânların biçimsel etkisi üzerinden hareketle bir tanımlama yapmak 
için, kenti ortaya çıkaran en önemli etmen olan kentliyi de göz ardı etmemek gerekmektedir. Nitekim kentsel mekân ile kent kimliği arasında da ilişki kurarken, kentlinin gerek mekânın oluşumuna ve mekân üzerinden de kentsel kimliğe olan katkısı yadsınamazdır. Kentsel mekânı kullanan birey yani kentli, kentsel kimliğe mekân üzerinden katkı yapmaktadır. Günümüz şehirciliği açısından ilk olarak "niçin böyle?" sorusuna cevap aramak yerine; ortaya çıkan kentsel formu, biçimsel açıdan ve kullanıcıların algısına dayanarak değerlendirmek gereklidir (Taşçı, 2014). Londra Üniversitesi Barlett Mimari Çalışmalar Ünitesi'nde Hillier, Hanson, Peponis, Hudson ve Burdet tarafından geliştirilen Mekân Dizimi (Space Syntax) Yöntemi, binaların, kentsel alanların, mimari ve kent planlarının biçimsel analizinde kullanılmaktadır. Mekân dizimi (Space Syntax), bina ölçeğinden kent ölçeğine kadar uzanan mekânsal boyutun biçimsel yapısı ile kullanım biçimi ya da o bölgede söz konusu olan eylemler arasındaki ilişkileri tanımlayan, bu ilişkileri sayısal bir yöntemle değerlendiren ve ortaya koyduğu yaklaşımlarla sosyal yapıyı da ilişkilendirerek mekân organizasyonunda yeni biçimlenmelere olanak tanıyan bir yöntemdir (Özyılmaz, 2009).

Mekân dizimi yöntemi, yerleşimin veri haritalarını, o yerin sosyolojik ve kültürel gelişme evreleri temel alınarak oluşturulan ve bu verilere göre saptamalar yapmak amaçlı geliştirilmiş bir metottur (Özkan Özbek, 2007). Sadece sayısal olarak farklı alanların değerlerini karşılaştırmak suretiyle kentlerin ve kentsel alanların mekânsal organizasyonunun temel özelliklerinden birini ortaya çıkarabiliriz: entegrasyon yapıları (Hillier ve diğerleri, 1983). Mekân dizimi yöntemi, kentin strüktürünü ve dilini üç önemli değerle analiz eder ve tarif eder. Bunlar; bağlama (connectivity), bütünleştirme (integration) ve anlaşılırıktır (intelligibility) (Hillier, 1984). Sosyokültürel teoriden çok, mimari ve kentsel çalışmalar için kullanılan mekân dizimi, analitik bir araç ve morfolojik bir yöntemdir. Bir yerleşmede yaşayan insan topluluklarının hareket yönleri, toplanma mekânları, doğrultuları, o yerleşmenin geometrisinin oluşturduğu sisteme göre belirlenmektedir. Yani aslında kentsel sistemin ya da strüktürün gerçekçiliği, o kentsel mekânı kullananların bu mekândaki dağılım sistemini belirlemektedir. Bir yerleşimde kentin strüktürel yapısıyla orantılı olarak ona uyum sağlayan sosyal topluluk, mekânla bütünleşerek kentsel devamlılığı sağlamaktadır. Nitekim zamanla, bina ölçeğinde veya kentsel sistemde görülen değişimler, eklemlenmeler, orada yaşayan sosyal topluluğun da değişmesine neden olmaktadır. Aynı zamanda kentler, sosyal, kültürel ve ekonomik açılardan değişime uğradıkça, kent formu da değişikliğe uğramıştır. Buradan hareketle kent formu ve sosyal topluluk arasındaki değişimin tam anlamıyla birbirlerini karşılıklı etkileyerek bir diyalektikle gerçekleştiğini söylemek mümkündür. Mekân dizimi yöntemi morfolojik yapıyla yerleşimin sosyal yapısı arasındaki ilişkiyi analiz etme ve tanımlama gibi bir görevi bulunmaktadır. Hatta bu yöntem, sosyal donelerden elde edilen ipuçlarıyla kentsel tasarım ve mimariyle ilgili sorunlara yanıt olacak olan spesifik projelerin de tasarlanmasına imkan tanımaktadır. Bilgisayar ile oluşturulan tasarımların aksine, gözlem ve analizler üzerinden birtakım sonuçlar çıkararak, sosyal donelere göre hareket eden mekânsal strüktürün oluşmasında da etkili bir yöntemdir (Özkan Özbek, 2007). Binaların ve şehirlerin mekânsal strüktürünün belli bir tanımıyla başlayan mekân diziminde mekâna ait bazı ögeler boşluklar olarak addedilmektedir (odalar, koridorlar, sokaklar, meydanlar, parklar, vb.). Kentler de bloklar arasında akan bir boşluk ağı tarafından bir arada tutulan binaların toplamıdır. Bu ağ, ayrı ayrı olan yapıyı bir araya getiren bir dizi sokak boşluklarını da birleştirir. Hepsini bir arada tutan şey bu ağın kendisidir. Bu ağ bir strüktürü teşkil etmektedir ve bu da belli bir geometriyi dolayısıyla da belirli bir bağlantı modelini ortaya koymaktadır (Al Sayed, 2018). Söz konusu metodun 4 farklı analiz biçimi bulunmaktadır (Çizelge 1):

Çizelge 1. Mekân dizimi yönteminde kullanılan yöntemler (Araştırma sürecinde oluşturulmuştur.)

\section{Mekan Dizimi}

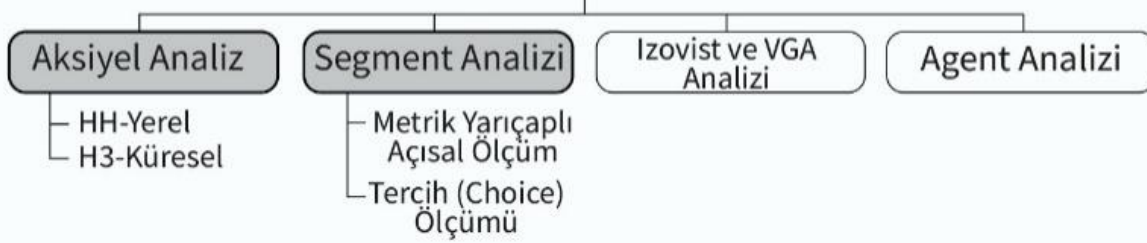




\subsection{Mekân Dizimine Yönelik Bazı Temel Kavramlar ve Açıklamalar}

Çalışmaların yapılması sürecinde temel altık haritalar oluşturulur. Aksiyel ve konveks haritalar bu haritalardan biridir. Konveks mekânlar basitçe açık alanları tanımlar ve her konveks mekân içinden en az bir aksiyel doğru geçer. Konveks mekânlar yerleşim özelliklerine göre daralır veya genişlerler. Bu konveks mekânlar arasındaki ilişkiler yerleşimlerin özelliklerini bize verir. Konveks mekânların devamlılı̆ı veya kopukluğu sınır yerleşimin sınır özelliklerini bize tanımlar. Aynı şekilde aksiyalite de yerleşimdeki açık alanların aksiyel uzantılarıdır. Bu uzantılar yerleşimin ne tür bir özelliğe sahip olduğunu gösterirler. Örneğin çok fazla kırılmaların olduğu bir yerleşim bütünleşme özelliği göstermez. Aksiyaliye mantığında en uzun doğrular en fazla algılanan doğrular olacağından bütünleşmenin güçlü olacağı ve erişimin kolay olacağı aksları belirlerler (Şekil 1 ve Şekil 2).

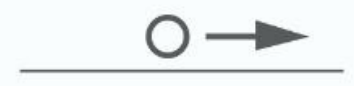

İnsanlar Çizgilerin Üzerinde Hareket Ederler

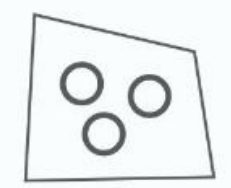

Konveks Mekanlarda İletişime Geçerler

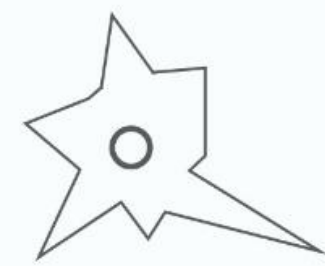

Yapılı Çevrede Hareket Ederlerken Görsel Alanların Değişimini Görürler

Şekil 1. Aksiyel ve konveks mekân (Hillier ve Vaughan, 2007)

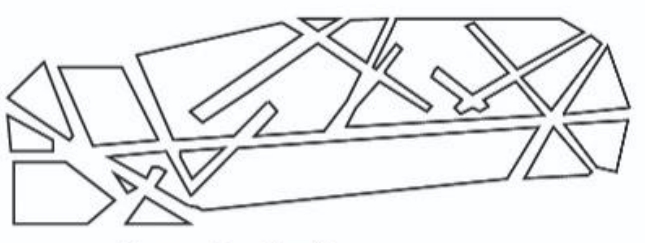

Konveks Harita

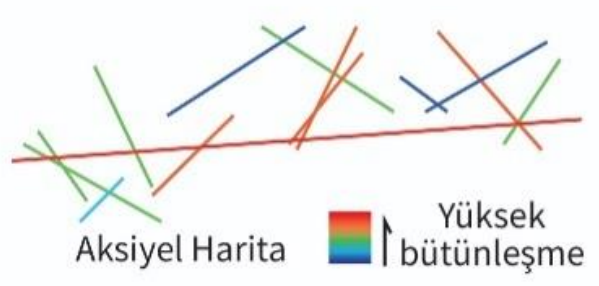

Şekil 2. Dışbükey (konveks) harita ve aksiyel harita analizlerine örnek (Al Sayed, 2018) (Düzenlenerek tekrar çizilmiştir.)

\subsubsection{Aksiyel analiz}

Mekân dizimi metodunun en önemli kavramı "entegrasyon"(Hillier ve Hnason, 1984) yani bütünleşme kavramıdır. Bu metotla kentsel sistem üzerindeki hareketlilik önceden tahmin edilebilmekte ve şimdiki hareketliliği açıklayacak veriler de üretilebilmektedir. Yerleşme alanlarının temelini aksiyel haritalar oluşturmaktadır. Bu haritalar yerleşmedeki hareket eden yayaların bulunduğu noktadan etrafına baktığında en uzun görüş mesafesini aktarmaktadır. Haritalar, yerleşmenin kamuya açık tüm açık alanlarından geçen en uzun ve en kısa doğrular çizilerek oluşturulur. Böylelikle sistemin uzunluğu metre cinsinden değil doğru sayıları ile ifade edilmiş olur. Aksiyel doğrular hareketliliği belirlemektedir. Hareket ederken dönüş yapmak zorunda kalındığında algılama mesafesi kısalmakta ve gidilecek yer görülemez olmaktadır. Dolayısıyla ikinci bir doğru diğer bir kesişme noktasına götürür. Böyle kırımaların çoğalması hareket edenlerin fazla uzağa gidememesine sebep olmaktadır. Bir yerleşime giren insanlar kırılmaların en az olduğu doğrusal akslar üzerinden yürümektedirler. Bu yürüyüş mesafesi esnasında da görüş mesafelerine göre hareketlerini yönlendirmektedirler. Sonuçta insanlar tarafından oluşturulan güvenli bir hareket dizisi ve mekânlar zinciri ortaya çıkmaktadır. Farklı farklı mekânlar arasındaki görüş noktaları, vistalar ve bina özellikleri kentsel mekânda hareket örüntüsü ile paralel yürümektedir. Mekân dizimi, binaların ve kentsel alanların temsilinde; hareketi ve kentsel kullanımı bir yerleşim düzeninin temel işlevleri olarak tanımlamakla başlar. Aksiyel analiz tipik olarak farklı yarıçaplar bazında yapılmaktadır. Bu da belirli bir çalışma alanı için bütünleşme değerinin, belirli bir adımdaki tüm çizgiler için hesaplandığı anlamına gelmektedir. Radius_3; yerel (local, HH3) entegrasyon ve radius_ $n$ ise küresel (global, HHN) entegrasyonu ifade etmektedir. Bu farklı entegrasyon ifadeleri çok önemlidir. Çünkü ayrı ayrı analiz edildiklerinde aktivite, eylemler ve kullanımlar gibi farklı özelliklerini sergilemeye başlamaktadırlar ki bu da kentsel mekânla 
ilişkilendirilebilecek bir analiz çıktısını teşkil etmektedir. Aksiyel analizin ana işlevi yaya hareketini tahmin etmektir ve bu analiz gerçek yaya sayısını öngörmemektedir (Özkan Özbek, 2007) (Şekil 3).
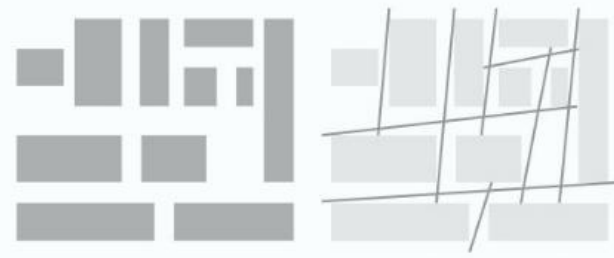

— Aksiyel Çizgiler

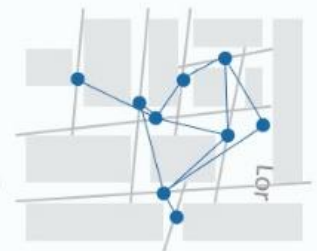

- Aksiyel Grafik
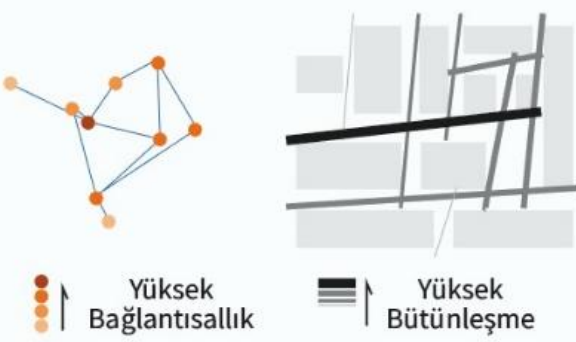

Şekil 3. Mekân dizimi metodunun kentsel bir alanda, aksiyel harita üzerindeki bir temsili (Al Sayed, 2018)

\subsubsection{Segment analizi}

Mekân dizimi metodunun bir analiz türü olarak kent mekânının hem topolojik hem de geometrik yapılanması için geçerli olan bir sentaktik gösterimdir. Kentsel yapıdaki doğrusal veya yarı doğrusal bağlantıları tespit etmek için segment analizindeki gibi bir temsile ihtiyaç duyulmaktadır. Bu nedenle topolojik konfigürasyonlar yerine açısal bir ölçüm kullanılmaktadır. En kullanışlı konfigürasyonel analiz yöntemi açısal derinliğe sahip olan mekânsal ağ üzerinden en kısa açısal yolculukları ana hatlarıyla belirtmektedir. Buradaki en çarpıcı nokta; yayaların yabancı bir çevrede yürürken bilişsel mesafeyi en aza indirgemesi muhtemel olduğundan, açısal analizlerin algısal yol bulma (wayfinding) ile iyi uyuştuğunun bulunmuş olmasıdır. Yerel hareket normalde en iyi yerel yarıçap ölçüsü ile temsil edilmektedir. Bu da 10 dakikalık yürüyüşe eşdeğer olan radius 800 ya da 1000 metredir. Açısal segment analizi ölçümlerinden birisi de "tercih (choice measure) ölçümü" dür. Seçim farklı yarıçaplar için Depthmap'te otomatik olarak hesaplanır. Temel olarak, yayalar tarafından en kısa yol olan her segment elemanının potansiyellerini hesaplar. Dolayısıyla tercih, bir mekânsal sistemde bir segmentin hareket potansiyelini göstermektedir (Al Sayed, 2018).

\subsection{Yol Bulma Yöntemine Yönelik Bazı Temel Kavramlar ve Açıklamalar}

Yol bulma, bireyin yaptığı seçimlerle mutlaka ilgili olan ve bilinmeyen (yabancı) bir ortamda yayanın belirli etkenlere göre kendi mekânını keşfetmesini sağlayan bir yöntemdir. Bir başlangıç noktası ile bir varış noktası arasındaki bir yolu veya güzergâhı belirleme ve izleme işlemidir. Amaçlı, yönlendirmeli bir faaliyettir. Lynch (1960) yol bulma ile ilgili olarak "dış ortamdan alınan belirli duyusal ipuçlarının tutarı bir şekilde kullanımı ve organizasyonu" olarak bahsetmektedir. Karar verme süreci olarak yol bulma, bireysel mekânsal karar verme sürecini ifade etmektedir. Birçok araştırmacı yol bulma ile mekân dizimi arasındaki güçlü ilişkiyi göstermiştir. Yaya daha bağlantılı ve daha bütünleşik olan mekânlara ulaşmaya çalışmaktadır. Bir yerleşimdeki şematik bir haritayı öğrenmek mekânsal bilgiyi etkilerken yol bulma davranışının üzerinde ise herhangi bir etkisi yoktur. Yol bulma davranışında yayaların eylemlerinin amaçları da önem teşkil etmektedir. Örneğin bir yol ağzında bulunan yaya, sağındaki ya da solundaki yolu seçebilir. Burada onun hareketini etkileyen bir eylemsel amaç vardır. Yolun sağında bir otobüs durağı varsa ve amacı otobüse gitmek ise o yolu tercih edecektir. Solunda bir kafe varsa ve amacı da bir şeyler içmek ise oraya doğru yolunu seçecektir. Çalışmada da yönlendirilmiş arama şekli kullanıldığından katıımcı yayaların, verilmiş olan belli nirengi noktaları arasında yol bulmaları onların eylemsel amaçlarını oluşturmuştur (Jansen, Heil ve Schmid, 2007).

Yol bulma davranışını birkaç faktör etkilemektedir. Bazıları yayaların; çevreye aşina olup olmadığı, kendileri için mevcut olan mekânsal bilginin türü, hedeflerinin niteliği ve mekânsal algılama yeteneklerinin ne olduğu gibi özellikle bireyle ilgili olanlardır. Mekânsal konfigürasyon gibi diğer faktörler ise çevrenin kendisi ile ilgilidir (Emo, 2014) (Şekil 4). 


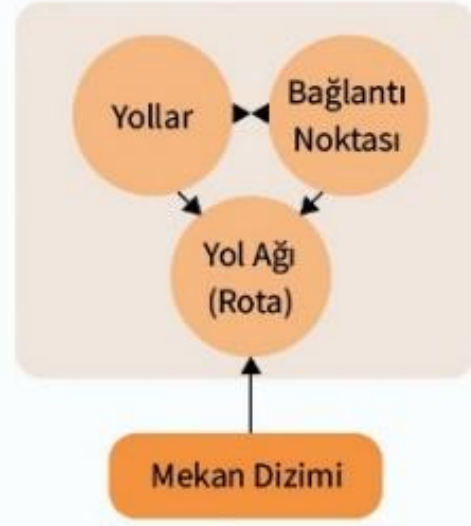

Şekil 4. Yol bulma yönteminin süreci (araştırma sürecinde üretilmiştir.)

\section{Rota ve Eylemsel Amaç}
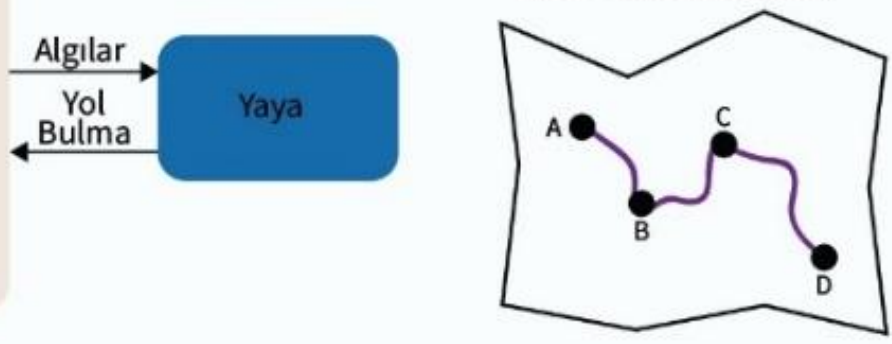

"Yol Bulma Metodu; Bir bașlangıç noktası ile bir varıș noktası arasındaki bir yolu veya güzergahı belirleme ve izleme ișlemidir. Amaçlı, yönlendirmeli bir faaliyettir."

Özetle; yol bulma tamamen rastgele gerçekleşen bir eylem değildir. Görsel algılamaya dayalı psikolojik kalıpları izlemektedir. Yön tayinindeki hareketlilikte, karar verme süreci önemlidir ve bu mutlaka bireyin yaptığı seçimlerle ilgilidir. Yol bulma metodunda özellikle katılımcı yayaların daha önce bulunmadığı bir yere gitmesi yöntemin varmak istediği nokta için önemli ve gereklidir (Şekil 5).

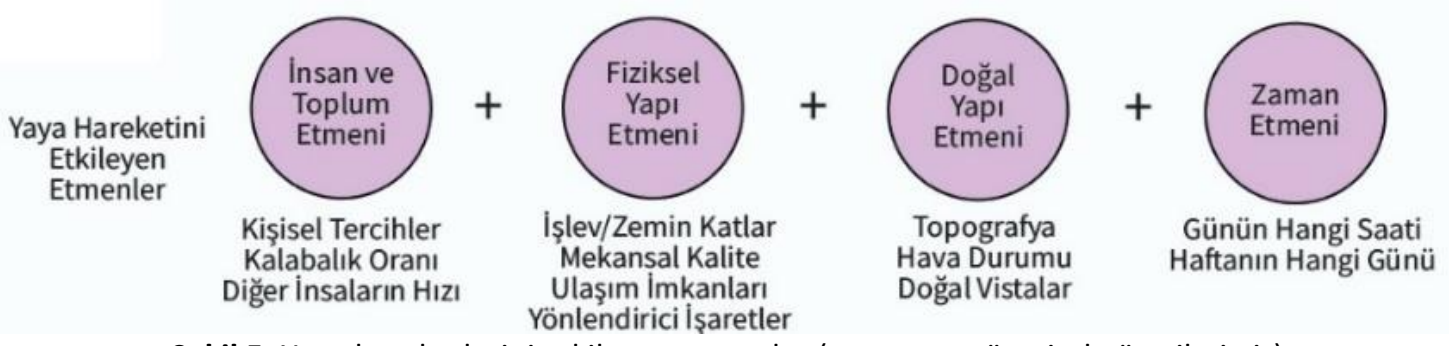

Şekil 5. Yaya hareketlerini etkileyen etmenler (araştırma sürecinde üretilmiştir)

\section{Bulgular ve Tartışma}

Kentsel mekânın değişimi çerçevesinde tarihsel süreç içerisinde 19. yy’ın sonlarına kadar çok büyük fiziksel değişikliklere uğramamış olan Kadıköy 20. yy'da hızla kentleşmiş, nüfusu artmış ve büyümüştür. 19. yy'ın sonlarına kadar bir köy ve sayfiye alanı olarak nitelendirebileceğimiz Kadıköy günümüzde İstanbul metropolünün küresel rekabet koşulları altında mekânsal gelişimini tamamlamış ve birtakım kentsel baskılar altında kalmıştır. Kısaca bu şekilde bir değişime sahne olmuş bu kent mekânında mekân dizimi ve yol bulma yöntemlerinin kullanılmasıyla hareketlilik, yerel ve metropol ölçeğinde bütünleşme durumu ile mekânsal kalite Kadıköy merkezinde ölçülebilecektir. Böyle bir çalışmaya uygun bir kentsel değişim süreci ve hareketliliği barındırdığı için Kadıköy çalışma alanı olarak seçilmiştir. Çalışma alanının sınırlarını belirleyen birtakım ögeler olmuştur. Bunlar kent merkezinin doğu, batı ve güneyi olmak üzere üç tarafını saran su ögesi, kuzeydoğusundaki otoyol ve demiryolu ile kuzeyindeki TCDD’nin arazisidir (Şekil 6). Bu şekilde kendiliğinden ortaya çıkan sınırlandıııı ögeler aynı zamanda çalışma alanının sınırlarını oluşturmuştur. Bu sınır birtakım analitik ölçümler ve analizlerin yapılmasını kolaylaştırmış ve anlamlandırmıştır. 


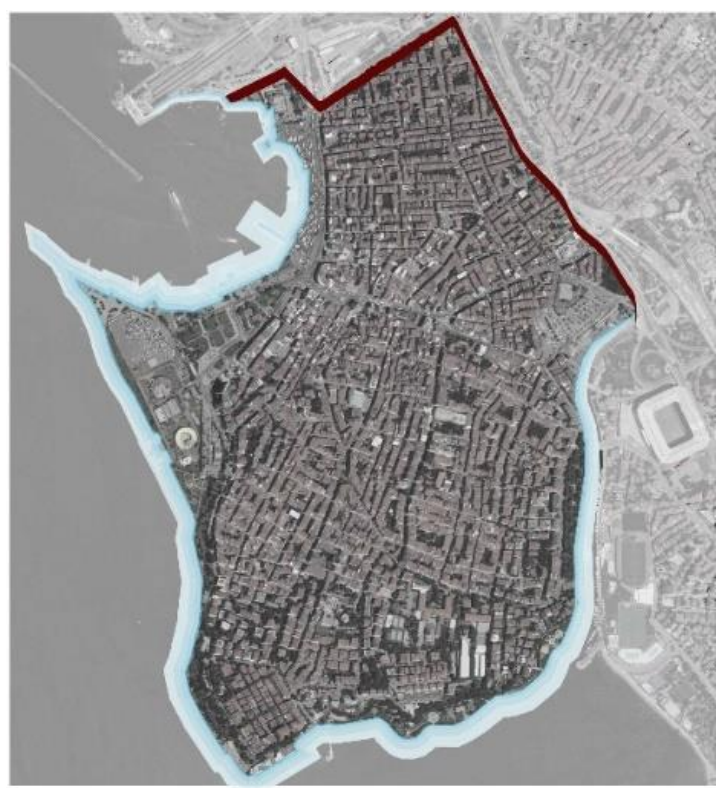

Şekil 6. Çalışma alanını belirleyen doğal ve yapay sınırlar

\subsection{Kadıköy'ün Mekânsal Gelişimi ve Önemli Fiziksel Değişimleri}

19. yy'ın başlarında askeri faaliyetlerin önem kazandığı Kadıköy, aynı yüzyılın ikinci yarısından itibaren kararı bir gelişim göstermeye başlamıştır. Kadıköy, bu yüzyılda sınırlarını Altıyol'a kadar genişletmiştir. Kadıköy'ün bu gelişiminde pay sahibi olan üç önemli olay vardır. Birincisi, 1856 yılında gerçekleşen yangındır. Yangının ardından Kadıköy'de bir ızgara plan uygulaması yapılmıştır. Bu uygulamayla çarşı içinde yapı adalarının köşelerinin kırılmasıyla meydancıklar oluşturulmuş ve doğrusal sokaklar açılımıştır. İkincisi, 1857 yılında başlayan buharlı gemi seferleridir. Üçüncü olay ise, 1871'te Haydarpaşaİzmit arasında tek hat olarak hizmete giren demiryoludur (Akbulut, 2004). Ayrıca 1896'da Üsküdar Sancağına bağlanınca Haydarpaşa çayırında 1899-1903 yılları arasında deniz doldurulmuştur. 20. yy.'ın hemen başında Haydarpaşa Askeri Hastanesi (1899) ve Haydarpaşa Garı (1908) gibi binaların tamamlanması ve Selimiye Kışlası'nın önem kazanmasıyla da gelişmeye başlamıştır (Şendur, 2010) (Şekil 7).
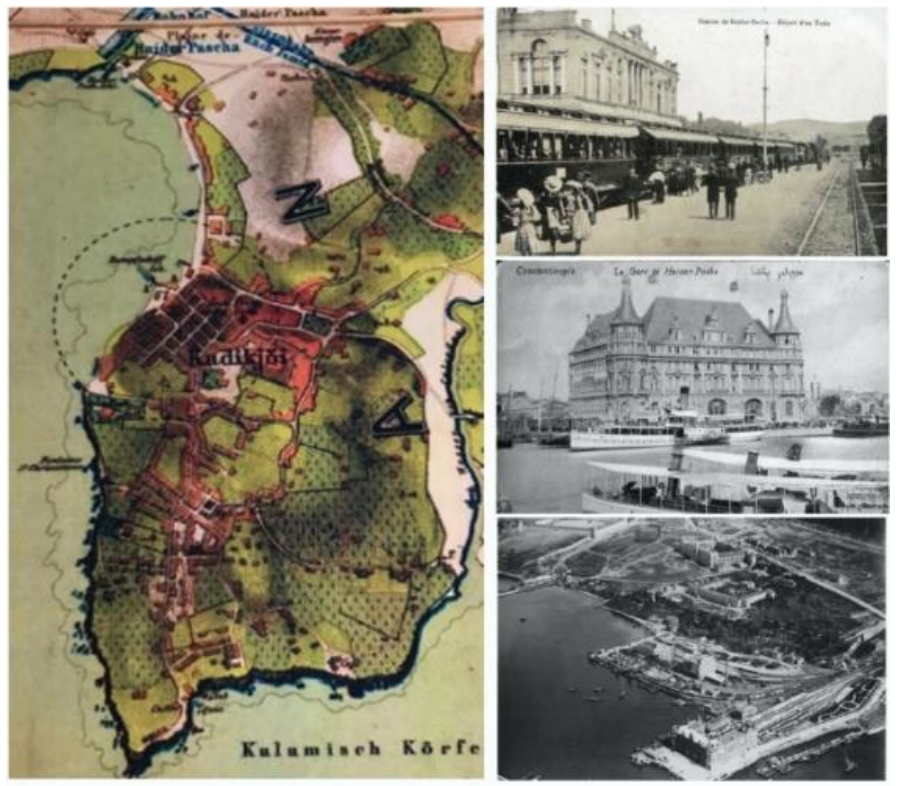

Şekil 7. 1882 Stolpe haritası ve Haydarpaşa Tren Garı (Kubilay, 2010), (Kentvedemiryolu, 2018), (Sebuhyan, 2018), (Pingudumuzayede, 2018)

Kadıköy 1930 yılında Üsküdar'dan bağımsız olarak ilçe özelliği kazanmış ve gelişimini devam ettirmiştir. $\mathrm{Bu}$ dönemde yangın sonrası oluşan planlı yerleşmeye ek, dar sokaklı organik bir dokudan çok, otomobillere uygun doğrusal sokakların açıldığı 1925 yılına ait Rahtre haritasından da görülmektedir. 
Kadıköy iskelesi 1926 senesinde inşa edilmiştir.1927 yılında ise şimdiki Haldun Taner Sahnesi zamanında Hal binası olarak İtalyan mimar U. Ferrari tarafından inşa edilmiştir. 1930'larda İstanbul'un imarı ile ilgili çalışmalarda Kadıköy için de bazı öneri ve projeler geliştirilmiştir. 1936-1951 arasında İstanbul Nazım Planı'nı hazırlayıp yönlendiren Prost Kadıköy'de bir stadyum, Fenerbahçe Yarımadası'nda da İçişleri Bakanlığı isteğiyle bir yat limanı düzenlemiştir. Kadıköy ve çevresinin de konut ve ticari kullanımların yer aldığı bir alan olarak değerlendirilmesini önerilmiştir.1936 yılında, Sabri Oran'ın plan teklifi ise kısmen gerçekleşebilmiştir. Bağdat Caddesi'nin genişletilmesi, Rıhtım Caddesi'nin önünün doldurulması uygulanan önerilerinin birkaçıdır. Yapılan uygulamalar; Rıhtım Caddesi'nin önünün doldurulması ve Bağdat Caddesi'nin genişletilmesidir (Gür, 2006) (Şekil 8).

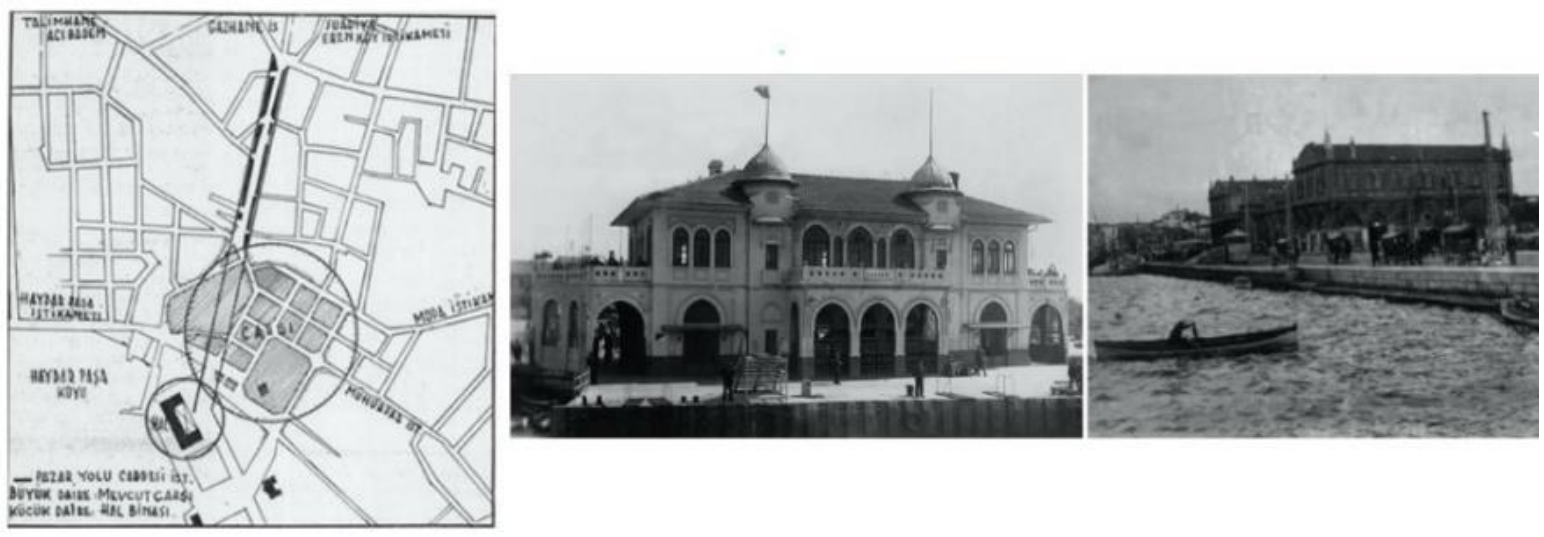

Şekil 8. Zeki Sayar'ın çizimi, tarihi iskele ve hal binası (Atılgan 2017a; 2017b)

1938-1950 yılları arasında dönemin mimarlarından Zeki Sayar, Hal Binası'nın Çarşı'ya uzak olmasını doğru bulmamaktadır. Altıyol Caddesi'ne inen parselin önünde binaların bulunmasının hal ile çarşının ilişkisini kestiğini söyleyerek bu binaların istimlak edilmesiyle ilişkinin kurulabileceğini savunmuştur (Gür, 2018). Hal Binası'nın 1938 yılında yıkılması düşünülmüştür. Bu tarihten sonra Altıyol'dan aşağı gelen caddenin üzerindeki istimlakler yapılıp yol açılmış ve sebze-meyve toptancılarına kullanma zorunluluğu getirilmiştir. 1940 yılında Hal olarak işletilmeye başlanmıştır. Sanayileşme ve iç göç etkisi ile 1950'lere gelindiğinde, İstanbul'un birçok yerleşim bölgesinde olduğu gibi Kadıköy'ün de mekânsal ve sosyal yapısında birtakım farklılaşmalar yaşanmıştır. 1953-1958 yılları arasında gerçekleştirilen Haydarpaşa Liman inşaatı ve Haydarpaşa-Pendik çift şeritli D-100 karayolu bölgeyi etkileyen önemli projelerdendir. 1960 'lardan sonra iskele meydanında, hal binası konservatuvara tahsis edilmiş, iskele ile hal arasındaki alan yayalara açılmış ve park düzenlemesi yapılmıştır. Dolgu alanlarla meydanın genişletilmesi meydan algısının yitirilmesine sebep olmuştur. 1993'te tamamlanan i̇skele-Mühürdar arasında deniz doldurularak meydan büyütülmüştür. Dolgu alanı üzerinde minibüs durakları bulunmaktadır. Aynı kıyı üzerinde motor iskelesi, IETT otobüs durakları, eski ve yeni vapur iskeleleri, eski Hal Binası, dolmuş durakları, iDO deniz otobüsleri iskelesi, polis merkezi ile yine yapay bir dolgu alanı üzerinde de iski Atık Su Arıtma Tesisi yer almaktadır. Kadıköy Meydanı olarak adlandırılan rıhtım bölgesi de bu dönemde önemli değişiklikler geçirmiştir. İskele ile eski Hal Binası arasında kalan alan trafiğe kapatılarak yaya kullanımına açılmıştır. Dolgunun güney kısmı bu amaç için kullanılırken, kuzeye doğru olan Haydarpaşa yönünde otobüs ve minibüs durak yerleri oluşturulmuştur. 2005 ve 2013 yılları arasında 1990'larda yapılan dolgu alanlarına ek büyük ölçekli doldurma işlemleri yapılmamıştır. Şekil 9 ve Şekil $10^{\prime}$ da anlaşılacağı üzere Kadıköy koyundaki dolgu alanlar özellikle $70^{\prime} l i$ ve $80^{\prime}$ li yıllardan sonra hızla ve büyük ölçekte müdahalelerle yapılmıştır. Doldurma işleri o tarihlerdeki kadar büyük ölçekte olmasa da 2016 yılında da İB, Kadıköy rıhtımını yeniden düzenleyerek birtakım doldurma faaliyetlerine başlamıştır. Alanı tamamen yaya kullanımına açmak ve otobüs duraklarını bulunduğu bölgeden kaldırmayı hedeflemektedirler (Gür, 2018). 


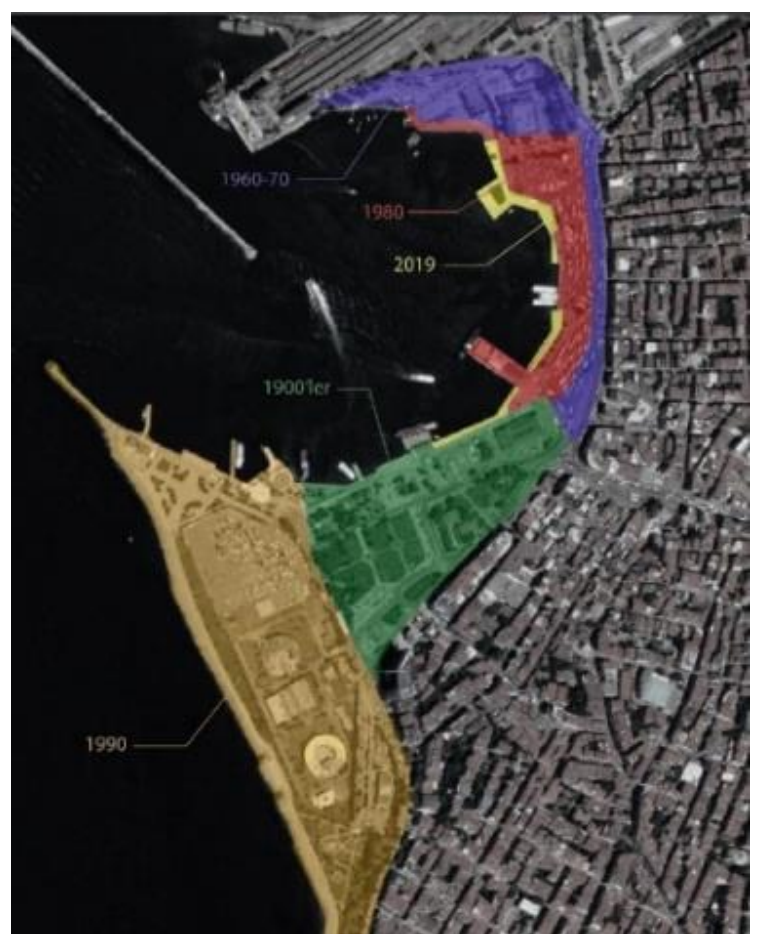

Şekil 9. Geçmişten günümüze Kadıköy koyundaki doldurulan alanlar (araştırma sürecinde üretilmiştir)

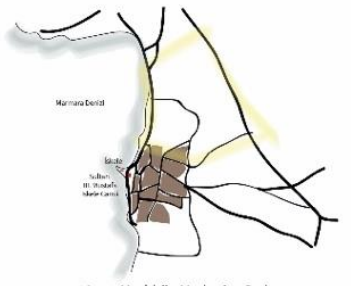

18. yy Kadıköy Yerleșim Dokusu

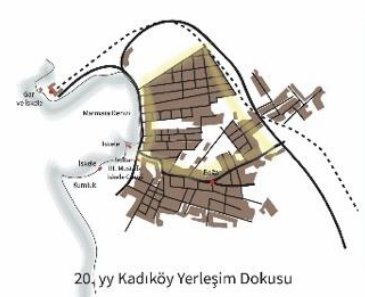

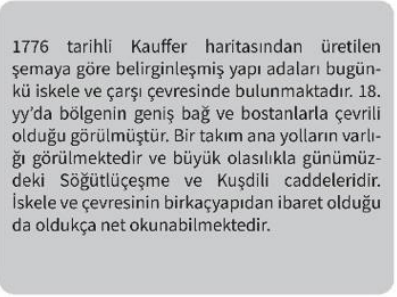

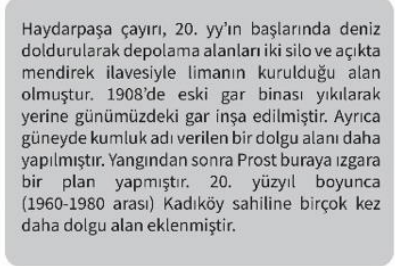

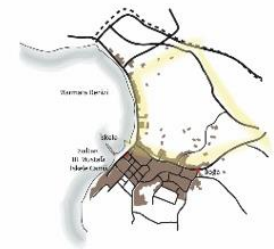

19. yy Kadıköy Yerleșim Dokusu

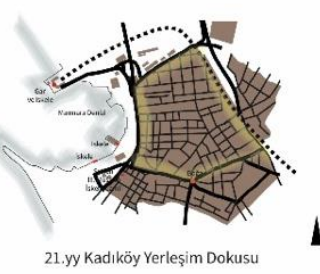

Kadıköy 18. yy.á kadar Rum ve Müslüman nüfusun iç içe yaşadığı yazlık kössklerle dolu bir sayfiye karakterine sahip olmuștur. 18. yy.'In ikinci yarısinda ordunun toplanma ve egitim alanı olarak kullandığı Yeldeğirmeni'nde 19. yy'in başında daha düzenli bir yerleșim olușmaya başladığı gorülmektedir. Ust düzey yôneticilerin de ilgi gösterdiği bir yazlik bölge haline gelmiștir ve mesire alani olarak da kullanilmiştr. Kadrrinin ordu atları için otlak vazifesini görmüştür.

Günümüzde yerleşim dokusu Kadıköy'ün her yerine yayılmısțtr. Bölgenin batısında yeni dolgu alanları inşa edilmiștir. Söğütlücesme, Altıyol ve eski hal binası ekseninde büyüyen Kadıköy'ün kuzey, güney, doğu ve batısından yoğun trafik akmaktadır. Hem denizyolu ve karayolu hem de raylı sistemlerle ulaşım imkanlarına sahip ola Kadıkoy Istanbul için onemli bir transfer merkezi görevini üstlenmiştir. Yoğun ticari faaliyetlerle ulaşımın getirdiği yük Kadıköy'ün tarihi merkezi için günden güne daha da yıpratıcı bir etkiy sebep olmaktadır.

Şekil 10. Kadıköy tarihi merkezinin mekânsal gelişimi (araştırma sürecinde üretilmiştir)

\subsection{Morfolojik Bir Metot Olan Mekân Dizimi (Space Syntax) Yöntemiyle Yapılan Analizler}

\subsubsection{Aksiyel analiz}

Kadıköy'ün tarihi merkezini kapsayan mekân dizimi metodunun aksiyel analizlerini içeren görseller bulunmaktadır. Burada değişimi okuyabilmek adına; aksiyel analizin hem 1930 yılı hem de günümüz haritaları kullanılarak lokal ya da yerel ve global ya da küresel bütünleşme değerleri Depthmap programı aracılığıyla üretilmiştir (Şekil 11). 


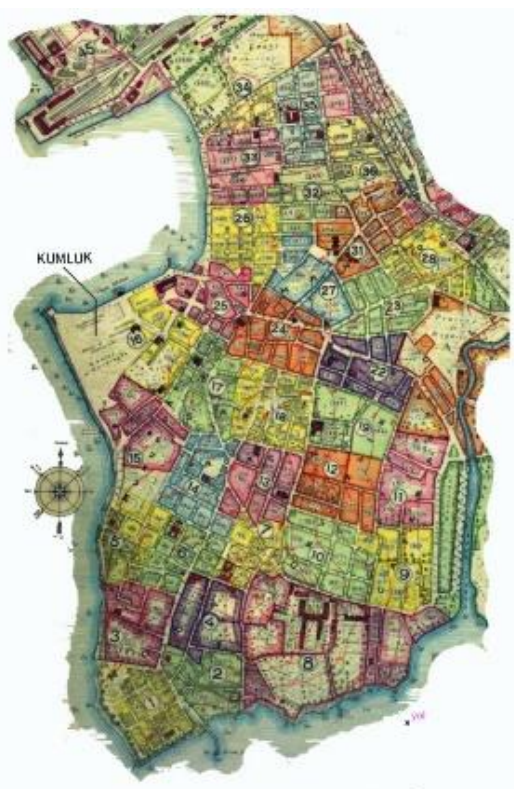

1930 YILI PERVITITCH HARITASI

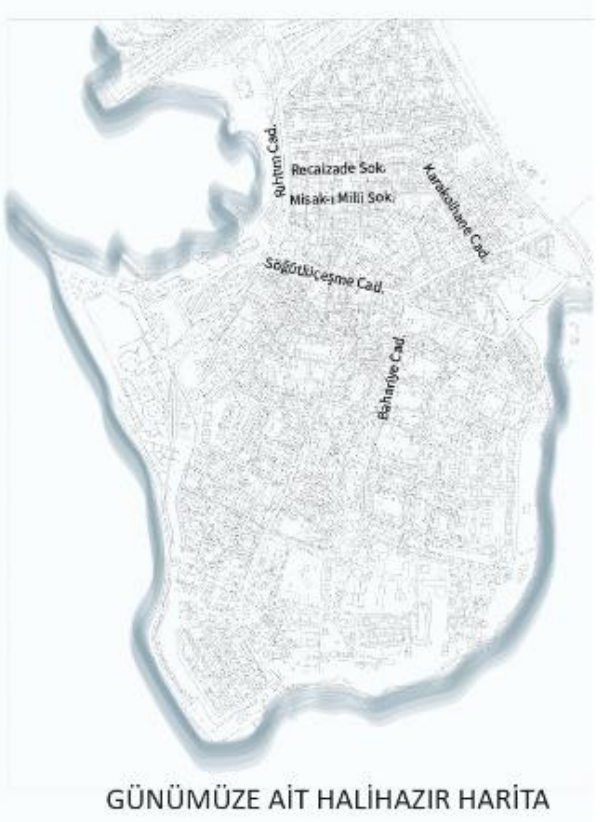

GÜNÜMÜZE AIT HALIHAZIR HARITA

Şekil 11. 1930 yılı Pervititch ve günümüz hâlihazır haritaları

Pervititch haritası altık olarak kullanılarak 1930 yılına ait ve günümüz halihazır haritası altık olarak kullanılarak 2018'e ait, sokakların/caddelerin öncelikle global sistemde aksiyel analizi yapılmış ve bütünleşme değerleri hesaplanmıştır. Kırmızıdan koyu maviye kadar bu değerlere göre aksiyel doğrular program aracılığıyla renklendirilmiştir. Kırmızı renkteki aksiyel doğrular en fazla global sistemle bütünleşmiş cadde ve sokakları ifade ederken koyu maviye doğru ilerledikçe aksiyel doğruların sistemle olan bütünleşme değerleri düşmektedir (Şekil 12).

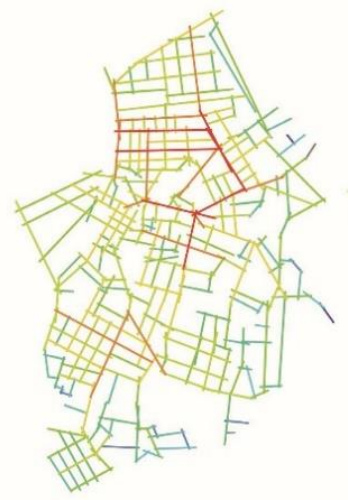

AKSIYEL ANALIZ (HH-KÜRESEL) / 1930

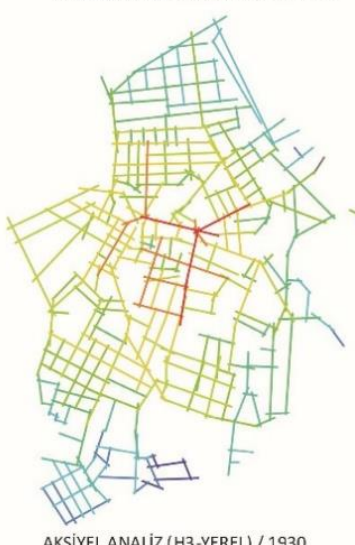

AKSIYYLL ANALIZ (H3-YEREL) / 1930

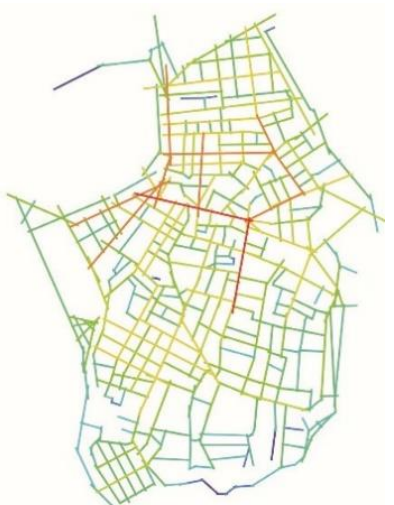

AKSIYEL ANALiZ (HH-KÜRESEL) / 2018

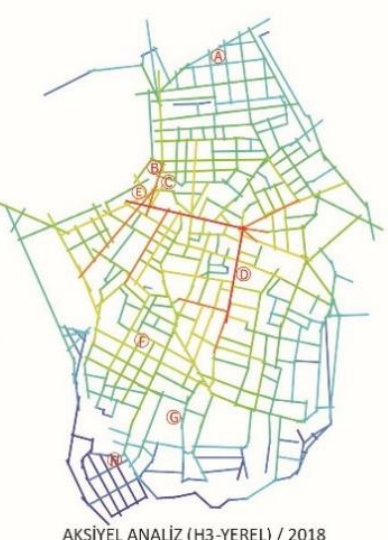

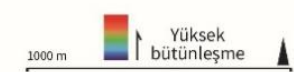

Şekil 12. Pervititch ve günümüz haritalarının bütünleşme analizleri 
1930 yılında küresel sistemde bütünleşme değeri en yüksek olan sokak ve caddeler: Söğütlüçeşme Caddesi, Bahariye Caddesi, Karakolhane Caddesi, Misak-ı Milli Sokağı ve Recaizade Sokağıdır. Günümüzde ise bütünleşme değeri en yüksek olan sokak ve caddelerden yalnızca ikisi ön plana çıkmaktadır: Söğütlüçeşme Caddesi ve Bahariye Caddesi. Bunun dışında 1930 ve 2018 yıllarının küresel sistemde bütünleşme değerlerini gösteren aksiyel haritaları bazı bölgeler haricinde benzerlik göstermektedir. Bunun önde gelen nedeni kent ızgarasının büyük oranda korunmuş olmasıdır. Farklı olan durumlardan biri şudur; Kadıköy'ün güneybatısındaki kumluk adı verilen bölgenin 1930'da sistemle daha bütünleşik olduğu görülmektedir. Diğeri ise Yeldeğirmeni'nin kuzey ve kuzeydoğu bölgesinin de yine günümüze göre sistemle olan bütünleşmesi daha fazladır. Aşağıda solda 1930'lu yıllardaki fotoğrafların günümüzdeki yeni durumları belgelenmiş ve bütünleşme değerlerine göre (kırmızı en yüksek sarı en düşük) sokaklar fotoğraflanmıştır (Şekil 13).
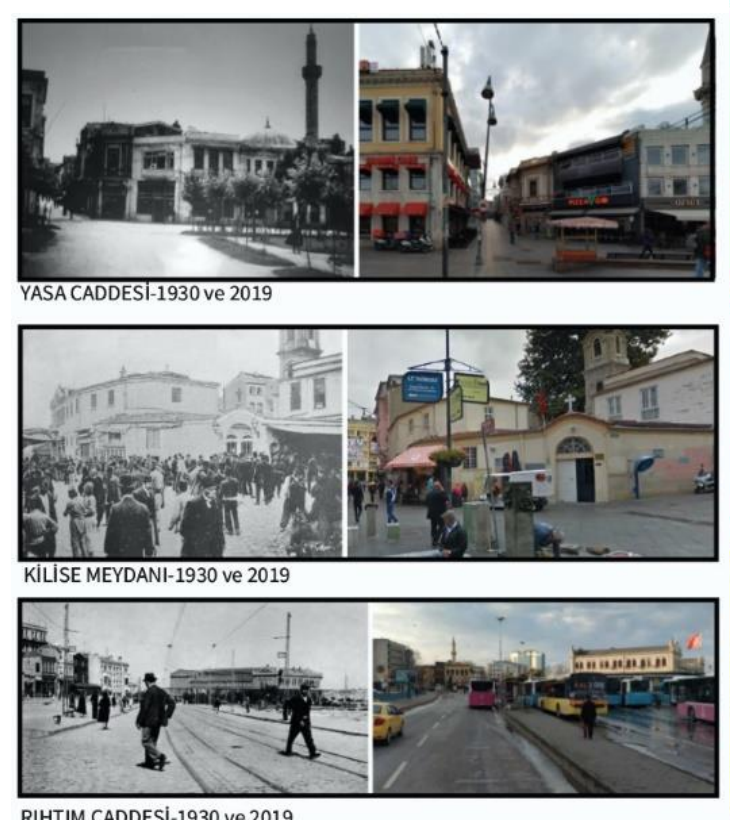

RIHTIM CADDESI-1930 ve 2019
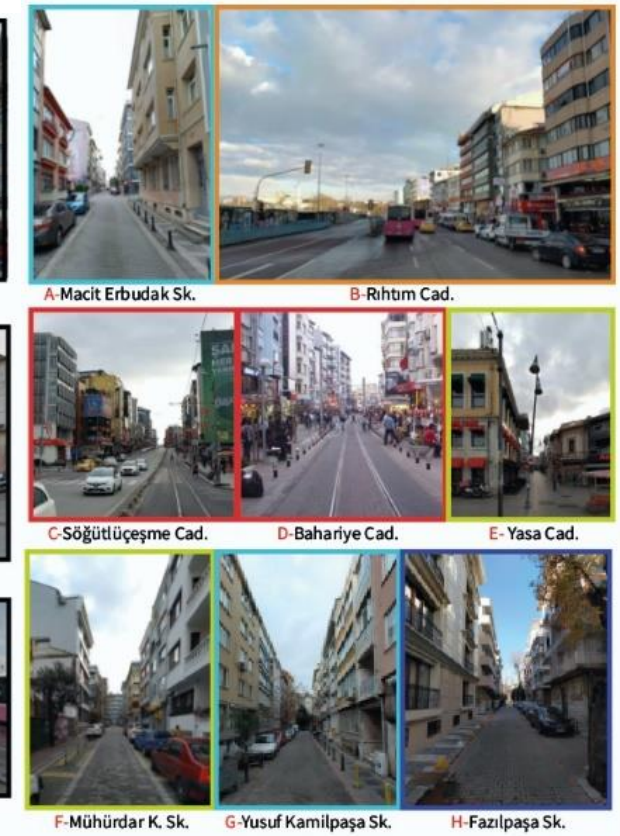

Şekil 13. Eski ve günümüz önemli aksların karşılaştırılması(solda) ve bütünleşme derecelerine göre sokaklar (sağda)

Mekân Dizimi dilinde kırmızı, turuncu ve sarı renklerde görülen sokak ve caddeler yerel sistemle iyi bütünleşmiş olan sokak ve caddelerdir. Bu durumla örtüşen ve aynı zamanda mekân dizimi-arazi kullanımı arasındaki ilişkiyi anlatan durum kentsel kullanımlardır. Kentsel kullanımlarda da yaya hareketini belirleyici olan kullanım büyük oranda ticari kullanımlardır. Yani yayalar ticari faaliyetlerin yoğun olduğu kentsel ızgarada daha yoğun olarak hareket etmektedirler (Şekil 14).

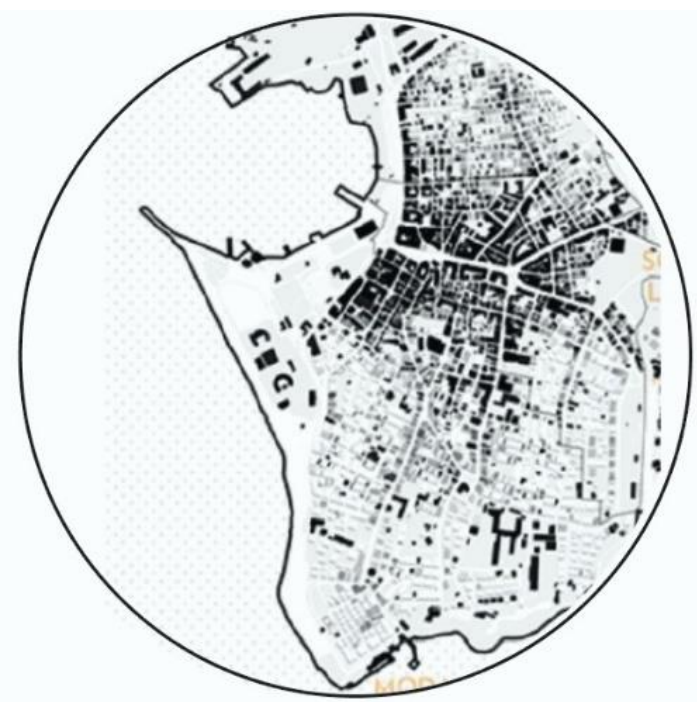

Şekil 14. Konut dışı kullanımlar siyah renkle gösterilen alanlardır (yoğunlukla ticari işlevler) (Data Mining, Geovisualation, Research, 2017) 
1930 yılı ve günümüzde de yerelde en iyi bütünleşmeyi gösteren caddeler aynı caddelerdir. (Söğütlüçeşme Caddesi ve Bahariye Caddesi). Bu caddelerin en iyi bütünleşmeyi göstermesinin sebepleri; kentsel ızgara içerisinde çok fazla sokakla kesişiyor olmaları, güvenli olmaları, fazla eğimli olmamaları, görüş mesafelerinin uzun olması, toplu taşıma duraklarının bulunması ve en önemlisi de ticari faaliyetlerin yoğun olarak bulunmasıdır. Farklı olan durum yine küresel sistemdeki gibi yerel sistemde de Yeldeğirmeni bölgesinin kuzey ve kuzeydoğusunun bütünleşme değerleri günümüze göre 1930 'da daha yüksek görülmesidir. 1930 yılı ve günümüzde de tarihi merkezin güney ve güneybatısını oluşturan Moda bölgesinin yerel sistemdeki bütünleşmenin en düşük olduğu yerdir. Buradaki sokaklar ızgara dokusunda olmasına rağmen bütünleşmeleri zayıftır. Bunun en önemli nedeni; kentsel işlevler, mekânsal kalite ve yerin coğrafi, konumsal özelliğidir. Bu bölge bir noktadan bir noktaya erişmek için değil, kullanııılar tarafından rekreatif kullanım isteğiyle kullanılan bir bölgedir. Konut kullanımlarının fazla olması sebebiyle de genel yaya hareketliliğinden uzak kalmaktadır.

\subsubsection{Segment analizi}

Çalışma alanı için yine 1930 yılı ve günümüze yönelik açısal segment analiz metodu olan tercih (choice) analizi ve metrik yarıçaplı açısal segment analizleri (radius $=1000 \mathrm{~m}$ ) yapılmıştır. Böylece bazı sokak ve caddeler yoğun olarak tercih edilen sokak ve caddeler şeklinde Depthmap programı aracılığıyla ortaya çıkarılmıştır (Şekil 15).
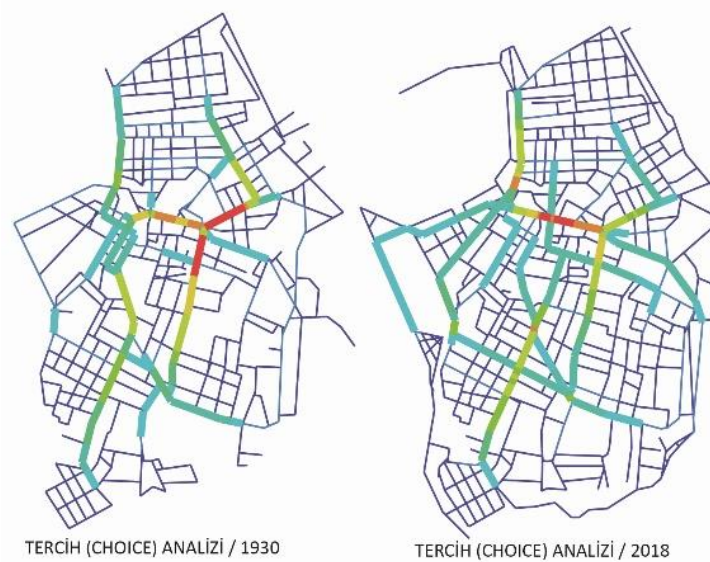
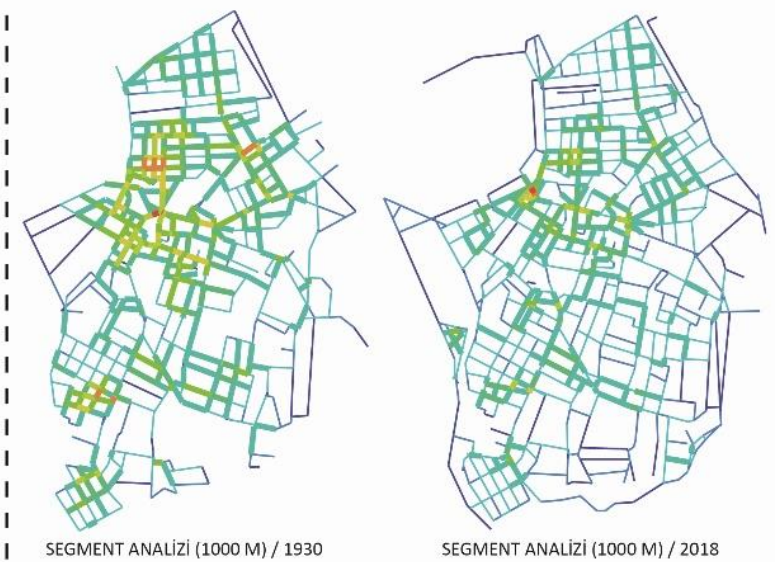

Şekil 15. 1930 ve günümüz Choice ve Segment analizleri karşılaştırmaları

1930 yılına göre tercih etme yoğunluğu için yapılan tercih (choice) analizinde sırasıyla; Bahariye Caddesi, Söğütlüçeşme Caddesi, Üzerlik Sokağı, Karakolhane Caddesi, Rıhtım Caddesi, Yasa Caddesi, Mühürdar Caddesi, Moda Caddesi, Dr. Esat Işık Caddesi, Serasker Caddesi, Halitağa Caddesi ve Kuşdili Caddeleri yoğun çıkmıştır. Günümüzde de yine aynı şekilde tercih etme yoğunluğu analizine göre sonucun 1930 yılındakine benzediği yandaki görsellerden de okunabilmektedir. Günümüze göre yapılmış olan analizde farklı olarak bazı caddeler arasındaki yoğunluk ve yönler değişirken bazı sokak ve caddeler ortaya çıkmıştır. Bunlar; Sakız Sokağı, Süleyman Paşa Sokağı, Rıhtım Caddesinin Kadıköy sahilinin güneyine uzanan kısmı, Moda Parkı Yoludur. Geçmişten günümüze tercih yoğunluğunda Bahariye ve Karakolhane Caddesinde azalma görülürken Sögütlüçeşme ve Rıhtım Caddelerinde artış görülmektedir. 1000 metre yarıçaplı açısal segment analizi de tercih analizini doğrulamakta ve örtüşmektedir. Bu kentlerin hat yapısını inceleyen analizin tercihlerle de paralel olduğunun göstergesidir. Bu analiz ayrıca kentsel mekânda yayaların nasıl gezindiğini göstermektedir. Aksiyel analiz başlığı altında bütünleşme değeri yüksek olan caddelerin ticari fonksiyonlarla doğrudan ilintili olduğundan bahsedilmişti. Bu durum aynı aksiyel analizde olduğu gibi segment analizlerinde de yine arazi kullanımı ve ticari fonksiyonların yoğunuyla doğrudan ilintili çıkmıştır. Bütünleşme değeri yüksek olan cadde ve sokakların tercih edilmesi söz konusu olmuştur. Metrik çaplı açısal segment analizi, tercih analizi ve aksiyel analiz bu noktada örtüşmektedir.

\subsection{Hareket ve Algı Esasına Dayanan Yol Bulma (Wayfinding) Yöntemiyle Yapılan Rota Çalışması}

Kadıköy tarihi merkezindeki yaya hareketliliğini anlamak amacıyla morfolojik bir yöntem olan Mekân Dizimi metodunun yanı sıra hareket ve algı esaslı yol bulma yöntemi olan Wayfinding metodu da 
kullanılmıştır. Bu metot yayaların yollarını bulurken nelerden etkilenerek tercih yaptıklarını da açıklamaktadır ve metot şu şekilde uygulanmıştır: Öncelikle Kadıköy kent merkezinde beş adet nirengi noktası (landmark) belirlenmiştir. Bu nirengi noktaları merkezin analiz edilebilmesini sağlayacak büyüklükte $1 \times 1 \mathrm{~km}^{2}$ bir alanın içerisinden belirlenmiştir. Belirlenen noktalar ise şunlar olmuştur: Kadıköy-Eminönü Vapur İskelesi, Kilise Meydanı, Balıkçılar Çarşısı, Boğa Heykeli ve Rasimpaşa kentsel sit alanından seçilmiş bir Art Nouveau apartman olan Velpreda İtalyan Apartmanı'dır (Şekil 16).

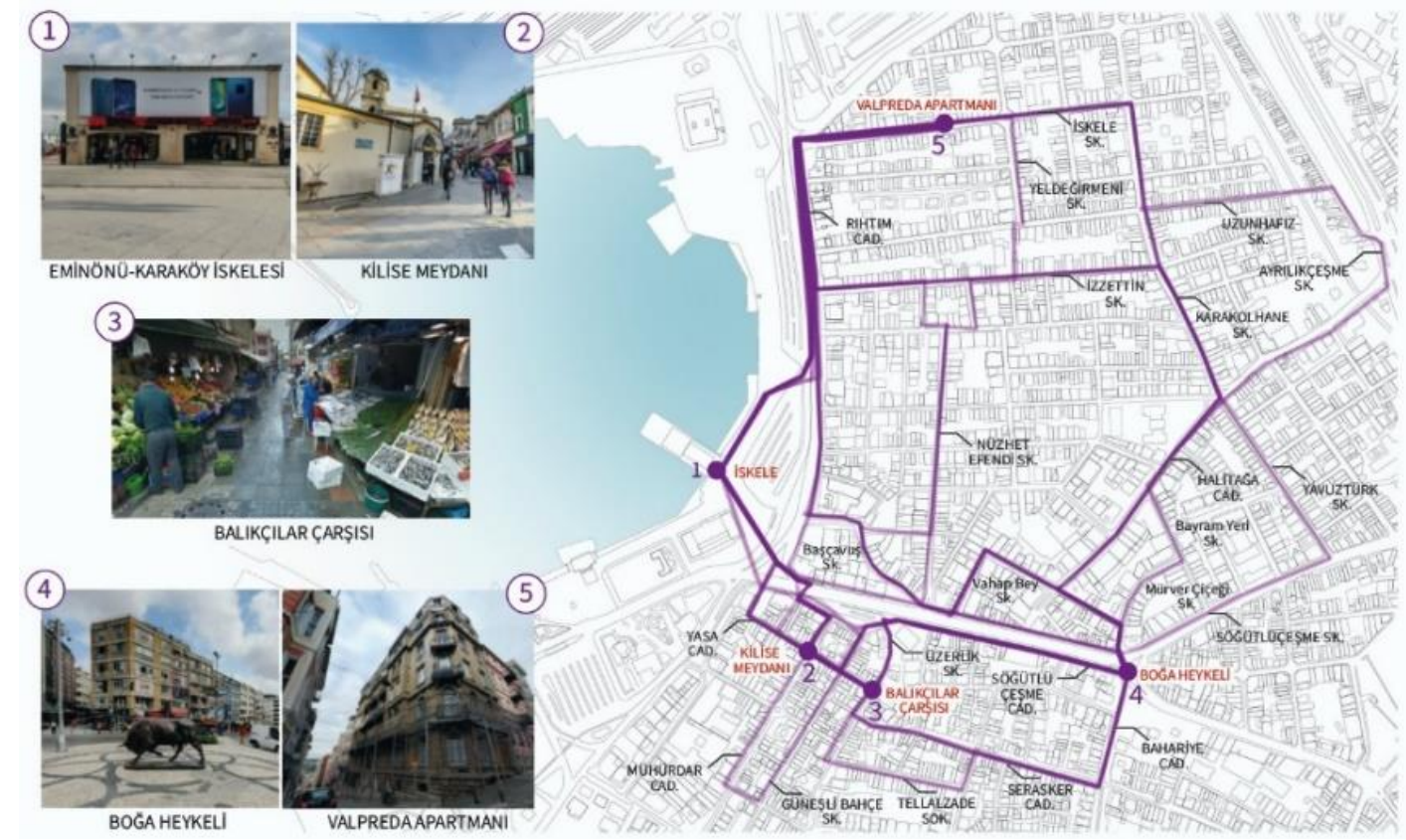

Şekil 16. Wayfinding yöntemi için kullanılan rota ve nirengi noktaları (koyu renklerden en fazla geçilmiştir)

Yönlendirilmiş arama (directed search) olan bu yol bulma çalışması için seçilen nirengi noktalarının bir "rota" oluşturması hedeflenmiştir. İskeleden başlanılarak; sırasıyla Kilise Meydanı, Balıkçılar Çarşısı, Boğa Heykeli, İtalyan Apartmanı ve yeniden iskele noktaları takip edilmiştir. Daha sonra aslında bir deney olan yol bulma çalışması kapsamında, görece önceden bölgeyi daha az deneyimlemiş ya da hiç deneyimlememiş farklı yaş ve cinsiyetten 10 kişi belirlenmiştir. Farklı zamanlarda her biriyle aynı rota istikametinde ayrı ayrı dolaşılarak yol bulma çalışması tamamlanmıştır. Rota üzerinde yürünürken herhangi bir şekilde navigasyon aleti kullanmadan ve dışarıdan bir yönlendirme yapılmadan deneyimleyen kişilerden söylenilen sırayla bahsi geçen nirengi noktalarını bularak ilerlemeleri istenmiştir. Yalnızca dijital olmayan bir haritaya bakılabilmiştir. Bu şekilde kendi hisleri ve kent ızgarasının verdiği algıyla birlikte yürüyen kişiler sonunda rotayı en son nokta olan apartmandan iskeleye doğru yeniden yürüyüp, yani başlangıç noktasına vararak tamamlamışlardır. Böylelikle belirlenen rota için farklı 10 adet hareket ağı oluşturulmuştur. Ortalama bir hareket ağının uzunluğu 2,4 km olmakla beraber bir hareket ağının ortalama tamamlanma süresi de 38,9 dk olmuştur.

Yukarıdaki harita üzerinde hangi sokak ve caddelerin yol bulma esnasında daha yoğun olarak kullanıldığı/tercih edildiği görülmektedir. Özellikle kent merkezinin batısında bulunan sahil boyunca ilerleyen Rıhtım Caddesi en yoğun tercih edilen caddelerden birisi olmuştur. Bu caddenin yanı sıra güneydeki Yasa Caddesi (tarihi çarşı içi) ve direkt Boğa Heykeline çıkan Söğütlüçeşme Caddesi de en yoğun tercih edilen caddelerdendir. İkincil olarak Vahap Bey Sokağı, Üzerlik Sokağı, Halitağa Caddesi, Karakolhane Caddesi ve İzzettin Sokağı yoğun olarak tercih edilmiş caddeler ve sokaklardandır. Bu beş nirengi noktasının tanımladığı rotayı tamamlayan diğer cadde ve sokaklar ise üçüncül derecede yoğun olarak tercih edilmiş cadde ve sokaklar olmuştur. Bu tercihler katılımcı yayaların algısal özellikleri ve mekânsal konfigürasyon (kent ızgarası, yükselti, eğim ve mekânsal kalite gibi niteliksel ve niceliksel özellikler) ile arazi kullanımının etkileşimleriyle oluşmuştur (Şekil 17). 

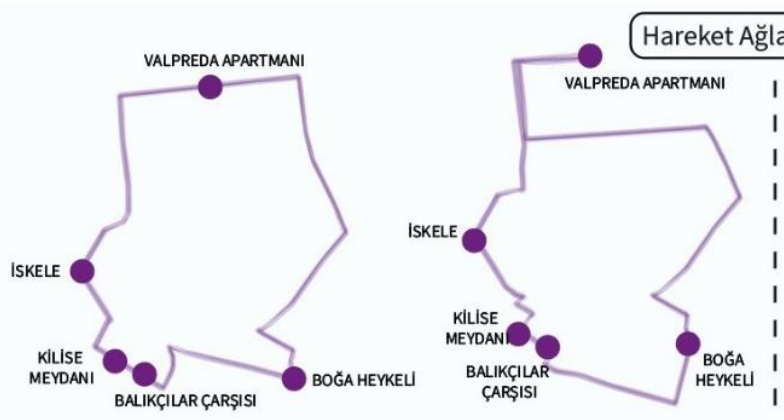

Bu iki hareket ağı da birbirine benzer şekilde oluşmuştur. Soldaki hareket ağında iskeleden yol bulma çalışmasına başlayan katılımc yaya Rıhtım Caddesinden hemen sonra Yasa Caddesine geçerek önce Kilise Meydanını ve aynı doğrultuda devam ederek de Balıkçılar Çarşısını bulmuştur. Buradan da Üzerlik Sokağı üzerinden Sögütlüçeşme Caddesine geçmiştir. Bu cadde boyunca ilerleyip Boğa Heykelini bulduktan sonra ise Vahap Bey Sokağından Halitağa Caddesine bağlanmıștır. Rotayı Yeldeğirmeni bölgesi üzerinden yürüyen katılımcı yaya Velpreda Apartmanını bulabilmek için Halitağa Caddesinden sonra Karakolhane Caddesi boyunca ilerlemiștir. Daha sonra beșinci nirengi noktası olan Velpreda Apartmanına erişebilmek için apartmanın bulunduğu sokak olan iskele Sokağa doğru yürümüştür. Son nirengi noktasından da iskeleye yeniden dönmek amacıyla da Rıhtım Caddesini kullanmıştır.

Sağdaki ikinci hareket ağı da soldakine benzer șekilde olușmuştur.
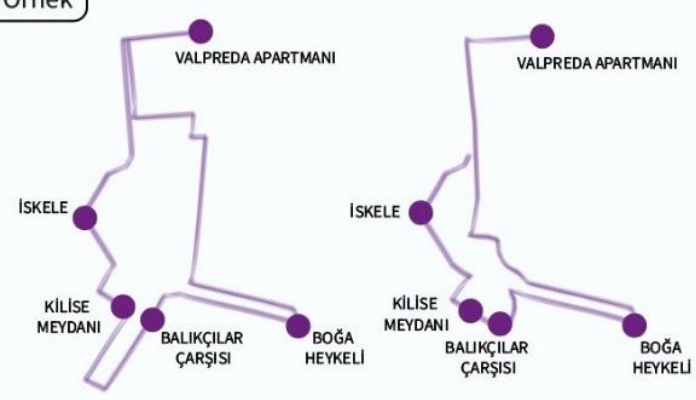

Yine bu iki hareket ağı da birbirine benzer șekilde olușan farklı ağlardır. Soldaki hareket ağında iskeleden başlayan ve yine iskelede sonlanacak olan rota istikametinde bütün nirengi noktalarına sırasıyla uğranılarak rotanın tamamlandığı okunabilmektedir. Bu hareket ağında iskeleden yol bulma çalışmasına başlayan katılım$\mathrm{Cl}$ yaya Rıhtım Caddesinden hemen sonra Yasa Caddesine geçerek önce Kilise Meydanını bulmuştur. Üçüncü nirengi noktası olan Balıkçılar Çarşısına erişmek için Mühürdar Caddesinden Güzel Bahçe Sokağına geçmiştir. Balıkçılar Çarşısını bulan katılımcı yaya Güzel Bahçe Sokağından direkt Söğütlüçeşme Caddesine geçmiştir. Caddenin sonunda Boğa Heykelini bulan katılımcı yaya yine aynı istikamet (Söğütlüçeşme Caddesi) üzerinden Nüzhet Efendi Sokağına girmiștir. Beșinci nirengi noktası olan Velpreda Apartmanına erişebilmek için buradan Rıhtım Caddesine ardından da İskele Sokağına geçen katılımcı yaya daha sonra rotayı tamamlayabilmek adına Rıhtım Caddesi üzerinden yeniden iskeleye ulaşmıştır.

Şekil 17. Gönüllü katılımcıların oluşturdukları hareket ağları

\subsection{Tespitler}

Insanların sokaklarda rahat yürüyebilmesi için maksimum eğimin \%6-7 oranında olduğu düşünüldüğünde çalışma alanının insanlar için eğim açısından zorlayıcı olduğunu söylemek mümkündür. Bu da sokak ve caddelerdeki tercihleri etkilemiştir. Nitekim Balıkçılar Çarşısından Boğa Heykeline doğru rota istikametinde ilerlemesi gereken katılımcı yayaların çoğunlukla Üzerlik Sokağı üzerinden Söğütlüçeşme Caddesine çıkıp oradan istenilen noktaya varmasındaki etkenlerden birisi de arazideki eğim olmuştur. Şekil 18 'de sarı renkteki çizgiler en yoğun ve yoğun olarak tercih edilmiş olan Rıhtım Caddesi, Yasa Caddesi, Söğütlüçeşme Caddesi, Vahap Bey Sokağı, Üzerlik Sokağı, Halitağa Caddesi, Karakolhane Caddesi ve İzzettin Sokağını göstermektedir (Şekil 18).
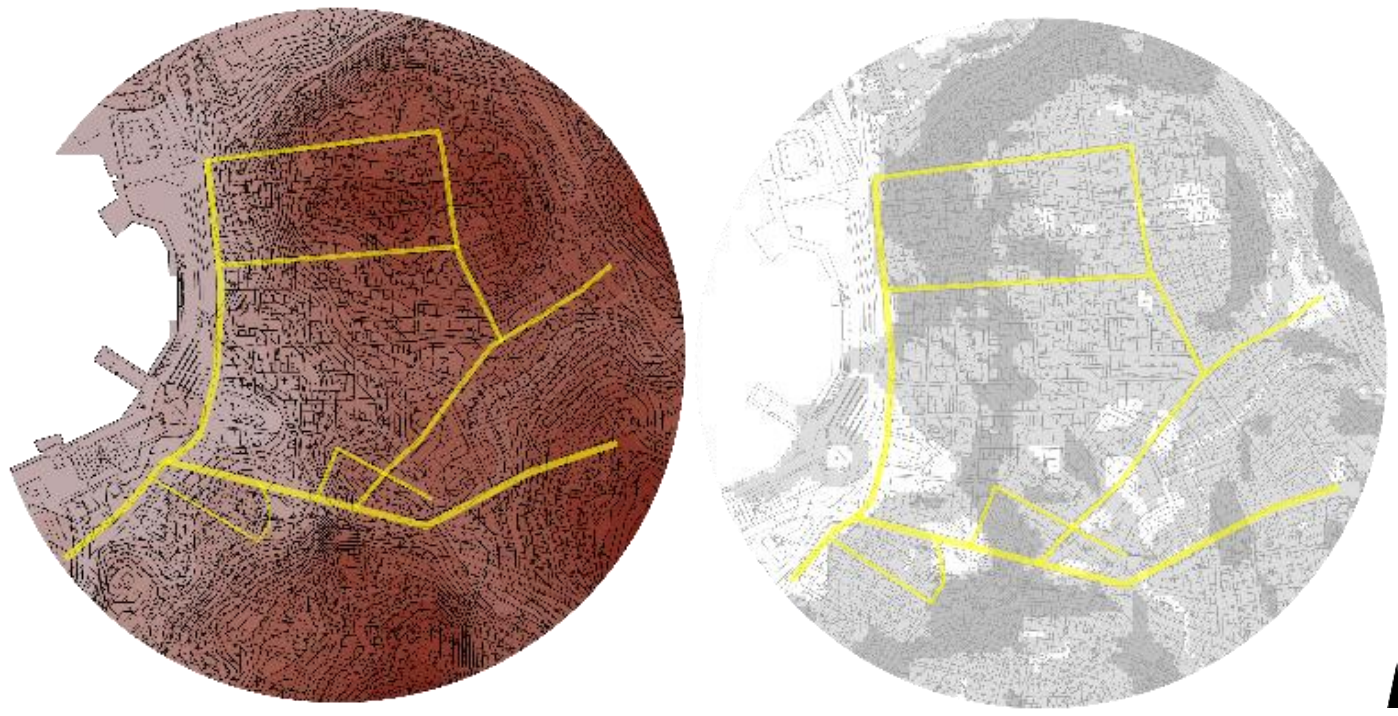

Şekil 18. Yükselti ve eğim analizleri

Şekil 18 'de özellikle ticari kullanımların yoğunlaştığı bölgelerdeki sokak ve caddelerin katılımcı yayaların tercih ettiği sokak ve caddelerle büyük oranda örtüştüğü görülebilmektedir. Buna örnek vermek gerekirse; zaten tarihi çarşı içerinde bulunan iki adet nirengi noktası (Kilise Meydanı ve Balıkçılar Çarşısı) ticari kullanımların varlığı sebebiyle yayalar tarafından yoğun olarak kullanılan bir bölgedir. 
Çalışmadaki katılımcı yayalar da bu noktalara erişebilmek için iskeleden hareketle başlayan rotayla Rıhtım Caddesini ve ardından da Yasa Caddesini kullanmışlardır (Şekil 19).

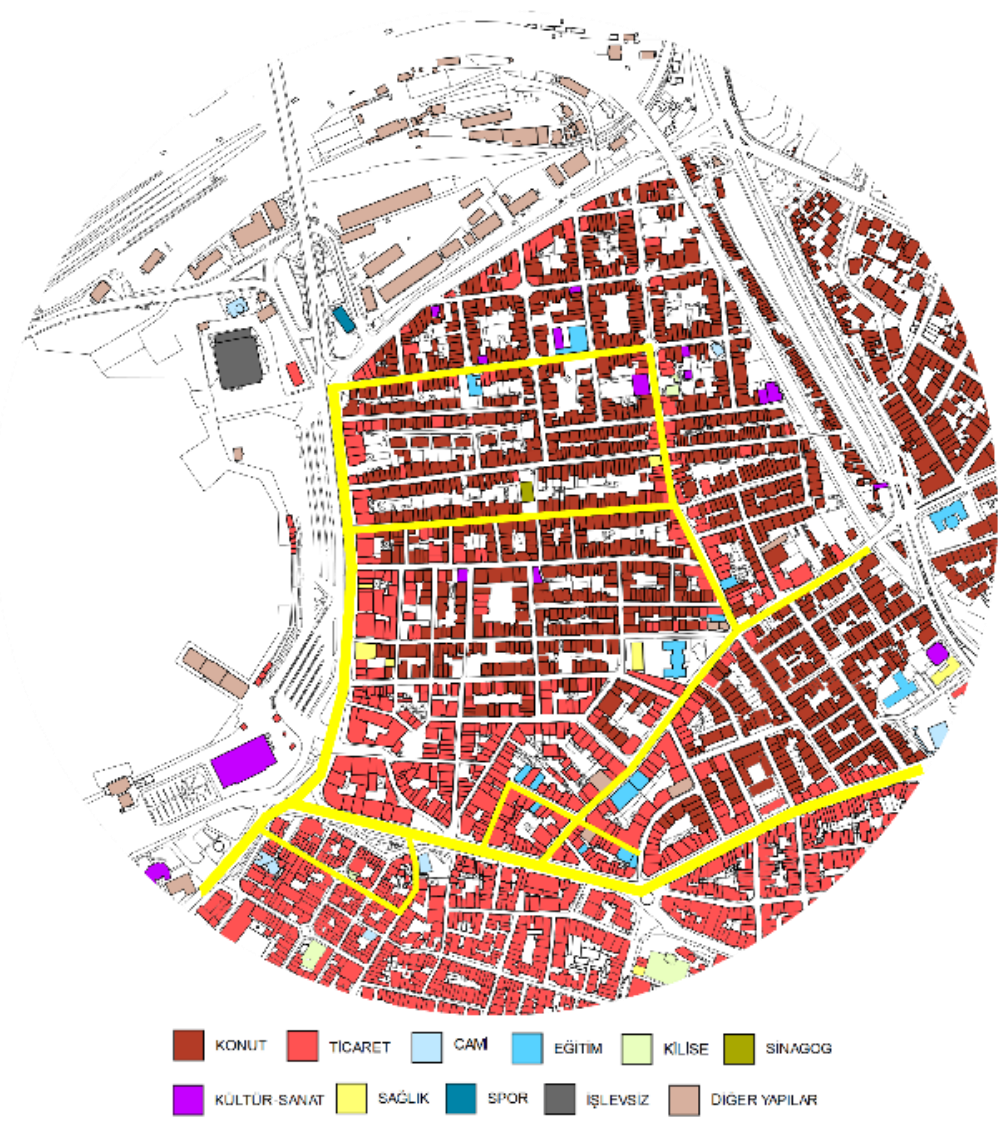

Şekil 19. Çalışma alanının arazi kullanımı

Diğer bir örnek, katılımcı yayaların dördüncü noktası olan Boğa Heykeline doğru yollarını bulurken cadde ve sokak seçiminde eğimden sonra etkili olan diğer bir unsur da Söğütlüçeşme caddesindeki ticari kullanımların varlığı olmuştur. Yine katılımcı yayaların Boğa Heykelinden hareketle Velpreda Apartmanına doğru yollarını bulurken en yoğun ve yoğun olarak kullandıkları Halitağa Caddesi ve Karakolhane Caddesi de ticari kullanımların yoğun olarak var olduğu caddelerdir. Bu ticari faaliyetlerin birçoğu da kafeler, restoranlar ve giyim mağazalarıdır.

Aktarılan bilgileri daha somut bir hale getirmek adına en yoğun (Rıhtım Caddesi) ve yoğun (Yasa Caddesi ve İzzettin Sokağı) olarak tercih edilmiş olan cadde ve sokaklardan bazıları hakkındaki tespitler yapılmıştır. Yol bulma çalışması sırasında çalışma alanında yoğun olarak tercih edilen bir sokak da İzzettin Sokağı olmuştur. Görselden de anlaşılacağı üzere bu sokak üzerinde tarihi ve tescilli yapılar bulunmaktadır. Yapılan gözlemler sonucu, sokak günün hemen hemen her saatinde yoğun olmayan bir yaya hareketliliğine sahiptir. Ancak bu durum sokağın tercih edilmemesine neden olmamıştır. Sokağın görüş mesafesi oldukça uzundur. Nitekim bu sokak batı yönünde rıhtıma açılmaktadır. Sokağın başından denizi görmek mümkündür (Şekil 20). 


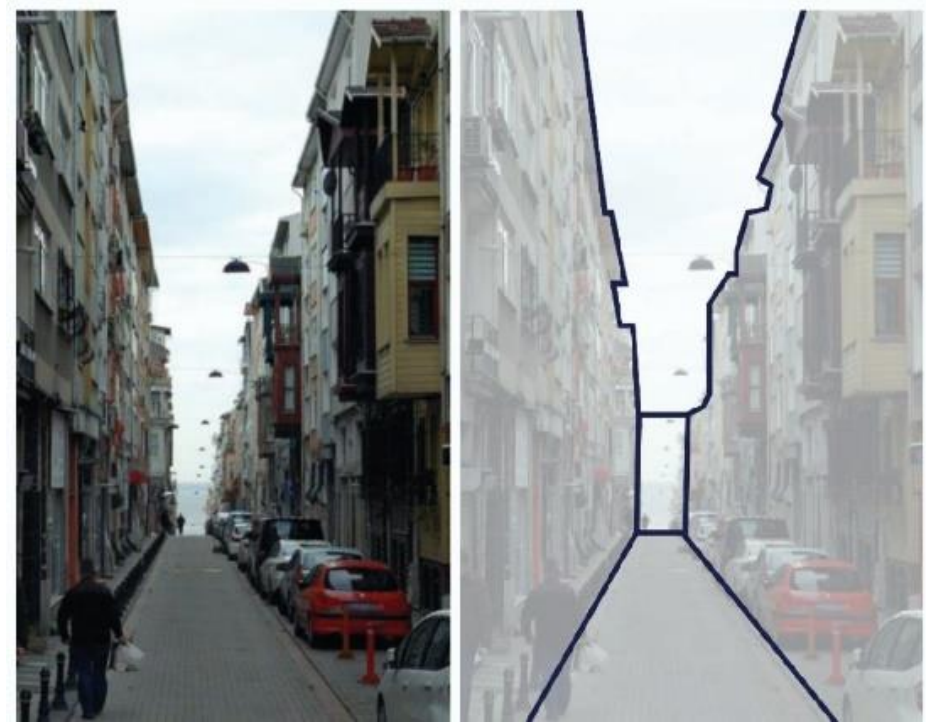

Şekil 20. İzzettin Sokağı

Yeldeğirmeni bölgesinin denize açılan önemli bir vistaya sahip birkaç sokağından biridir. Aynı zamanda bu sokak yine yayalar için güvenli bir sokaktır. Sokak eğimlidir (maksimum eğim; \%13,3) ve ortalama eğimi \%6,4'tür. Üzerindeki yapıların tamamına yakını konut işlevine sahiptir. Az da olsa yayayla etkileşen zemin katlarında; kafe ve bakkal gibi ticari kullanımlar mevcuttur. Sokağın mekânsal kalitesi genel itibariyle iyi seviyededir. Yapı durumları yine geneli itibariyle iyi durumdadır (Şekil 21).
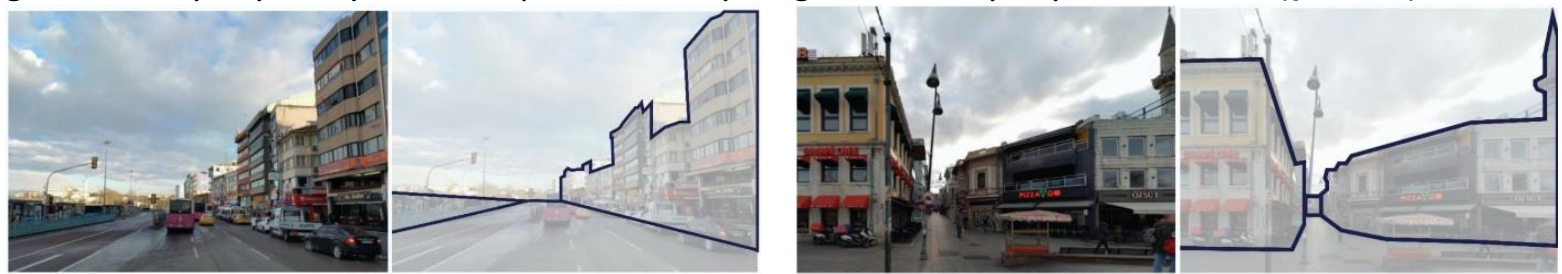

Şekil 21. Rıhtım Caddesi ve Yasa Caddesi

Yol bulma çalışması sırasında çalışma alanında en yoğun tercih edilen cadde olan Rıhtım Caddesi yukarıdaki görselden de anlaşılacağı üzere otobüs peronlarıyla apartmanların arasındaki bir caddedir. Yapılan gözlemler sonucu, cadde günün hemen hemen her saatinde yoğun bir yaya akışına sahiptir. Caddenin görüş mesafesi uzundur. Aynı zamanda burası yayalar için güvenli bir caddedir. Çünkü gece ve gündüz aktif olarak kullanılmaktadır. Caddenin ortalama eğimi \%1,8'dir. Caddenin üzerindeki yapıların \%90'ı ticari işleve sahiptir. Özellikle yayayla etkileşen zemin katlarda; restoran, kafe, turizm acentesi, bakkal vb. kullanımlar mevcuttur. Caddenin mekânsal kalitesi iyi seviyededir. Yapı durumları iyi ve bakımlıdır. Yayanın yürüyebilmesi için yeterli genişlikte bir kaldırım alanı bulunmaktadır. Çalışmadaki katılımcı yayaların bu caddeyi kullanmadaki bireysel algılarının yönlenmesinde bu etmenler rol oynamıştır.

Yol bulma çalışması sırasında çalışma alanında en yoğun olarak tercih edilen diğer bir cadde de Yasa Caddesidir. Yukarıdaki görselden de anlaşılacağı üzere bu cadde üzerinde tarihi ve tescilli yapılar bulunmaktadır. Yapılan gözlemler sonucu, cadde günün hemen hemen her saatinde yoğun bir yaya akışına sahiptir. Caddenin görüş mesafesi uzundur ve rıhtımdan bakıldığında kilise meydanını görmektedir. Aynı zamanda burası yine yayalar için güvenli bir caddedir. Çünkü gece ve gündüz aktif olarak kullanılmaktadır. Caddenin ortalama eğimi \%4,5'dir. Caddenin üzerindeki yapıların \%90'ı yine ticari işleve sahiptir. Özellikle yayayla etkileşen zemin katlarda; restoran, kafe, giyim dükkanı, kitapçı vb. kullanımlar mevcuttur. Caddenin mekânsal kalitesi iyi seviyededir. Yapı durumları iyi ve bakımlıdır. Tamamen yayalaştırılmış olan bu cadde yayaların yürüyebilmeleri açısından uygundur

\section{Sonuç ve Öneriler}

Çalışma alanında yapılmış olan rota çalışması ile açısal segment analizinin bir türü olan tercih (choice) analizinin birbiriyle olan bağlantısı değerlendirilmiştir. Çalışmada özellikle tercih analizinin seçilmesinin sebebi rota çalışmasının da tercih ve bireysel algılara göre yapılmasıyla ilgili olmasıdır. (Şekil 22) 
Aşağıdaki görselde tercih analizi ve rota çalışmasının çakıştırılması sonucu iki verinin de birbiriyle örtüştüğü görülmektedir. Mor renkte ifade edilmiş olan çizgiler tüm katılımcı yayaların oluşturduğu hareket ağlarını ifade etmektedir. Katılımcı yayaların tercih ettiği sokak ve caddeler $\% 90$ oranında segment analizindeki tercih ölçümünün tespit etmiş olduğu sokak ve caddeler ile örtüşmektedir. Bunlar; Bahariye Caddesi, Söğütlüçeşme Caddesi, Üzerlik Sokağı, Karakolhane Caddesi, Rıhtım Caddesi, Yasa Caddesi, Mühürdar Caddesi, Moda Caddesi, Dr. Esat Işık Caddesi, Serasker Caddesi, Halitağa Caddesi ve Kuşdili Caddesidir. Hareket ağlarının Yeldeğirmeni bölgesinde oluşması rota çalışmasının varılması gerekli son nirengi noktası olan Valpreda Apartmanının orada bulunmasıdır. Mekân Dizimi yönteminin en önemli araştırma konusu olan yaya hareketliliğinin kentsel aktivite alanlarıyla olan yoğun ilişkisi olduğu varsayımından yola çıkılarak yapılan bu karşılaştırmalı iki analizde morfolojik ve sentaktik bir analiz metodu olan mekân dizimi yönteminin sonucuyla çalışma alanında yapılan hareket ve algı esaslı bir deneyi içeren rota çalışmasının sonucunun örtüşmüş olmasıdır. Buradan hareketle yayalar kent mekânında yollarını ya da herhangi bir noktayı bulmaya çalışırken en kısa yoldan kent ızgarasının yönlendirmesi (mekânsal konfigürasyon) ve bireysel algılarıyla da kentsel fonksiyonlardan ticari ve kamusal aktivitelerin yoğunlaştığı, mekânsal kalitesi iyi, görüş mesafesi uzun ve güvenli olan cadde ve sokakları tercih etmektedirler.

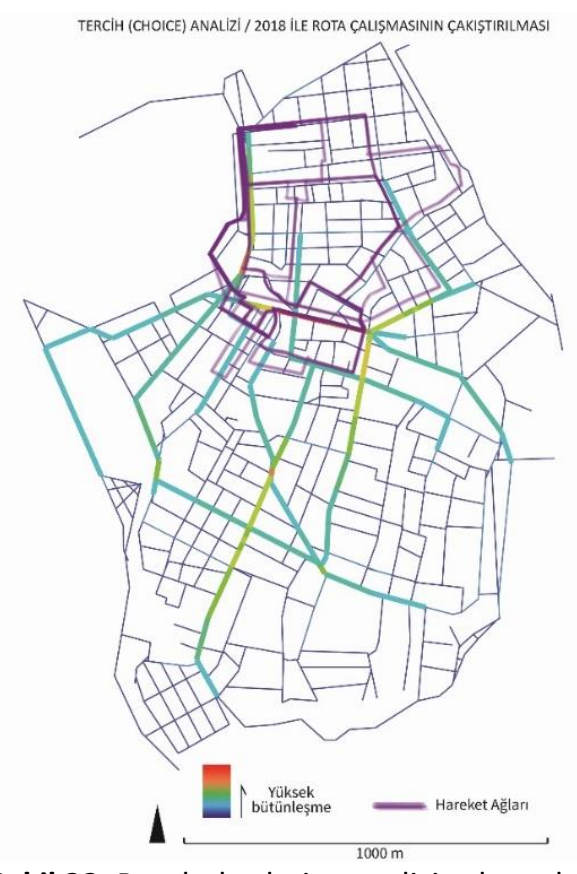

Şekil 22. Rotalarla choice analizi çakıştırılması

Sosyal ve fiziksel katmanlara sahip olan kent dokuları, barındırdıkları ağ sistemleri ve bu ağın içerisinde hareket eden yayalar ile birlikte kentsel dokunun canlıı̆̆ını ve o kentsel mekânın ne derece yoğun kullanıldığı ile doğrudan ilintili hale getirmektedirler. Çünkü kentsel mekânlar gün içerisinde; alışveriş, dinlenme ve rekreatif faaliyetler, eğlence ve çalışma gibi çeşitli gereksinimlerin karşılanması için devamlı bir hareket ve akış halindedir. Bu hareketliliği sağlayanlar kentin asıl kullanıcıları olan yayalar, gündelik yaşamları içerisinde belirli mekânlardan belirli mekânlara doğru sürekli bir hareket içerisindedir. Kent parçalarının içerisinde yayalar günlük hayatlarında kendilerine özgü hedef ve amaçlar istikametinde kentsel dokuları içerisinde hareket ederler.

Elbette bu hareket dizisi sürecinde bireysel duyumsama ve algı mekanizmalarına bağlı olarak farklı tercih ve yönelmeler gerçekleşebilmektedir. Yayaların içerisinde hareket halinde bulunduğu kentsel mekânlar devamlı olarak bu algı mekanizmasını uyaran uyarıcılar üretmektedir. Bu uyarıcılar da yayaların kentsel mekân içerisindeki hareket etmelerinde rol oynayan psikolojilerini etkilemektedir. Bu akış yayaların amaçları çerçevesinde gerçekleşmektedir. Buradaki önemli olan nokta, yayaların amaçları çerçevesinde kentsel mekân içerisinde hareket ederken kullandığı cadde ve sokakları hangi etmenlerin etkisinde tercih ettiğinin tespit edilebilmesidir. Böylelikle o kentsel mekânı daha iyi analiz ederek anlamak ve sorunlarına çözüm getirebilmek kolaylaşmaktadır. Çünkü yoğunluğun çok olduğu iş ve ticaret merkezlerinin hem taşıt hem de yaya akışının karşılıklı olan olumsuz etkilerini minimum 
düzeyde tutmak, günümüz çağdaş kentsel tasarım ve şehir planlama anlayışı içerisinde başka yeni arayışlar gerektirmektedir. Çalışmada temel olarak yaya hareketlilik dokusu incelenerek bu hareketliliğin kentlerdeki arazi kullanımı ve mekânsal kalite ile ilgisinin olduğu açığa çıkarılmaya çalışılmıştır. Farklı boyutlarda yapılan analizler ve karşılaştırmalı irdelenen sonuçlar doğrultusunda bu çalışma, yaya hareketliliği ile arazi kullanımı ve mekânsal kalite ve yerin coğrafi özellikleri arasında anlamlı ve paralel bir ilişki olduğunu göstermeye çalışmıştır.

Kadıköy, kentsel sit alanına sahip yoğun nüfuslu bir kent parçası olarak merkez mekân, tarihsel arka plan gibi olumlu yönlerinin yanı sıra, transfer merkezi yükü, yaya-taşıt trafiğinin düzensizliği, ticaret işlevinin getirdiği yoğunluk, atıl kalan yapıların varlığı, tanımsız kent boşlukları gibi olumsuz yönlerinin baskısı altında kalmıştır. íki yöntemin de analiz sonuçlarına göre kent mekânının kullanıcıları Kadıköy'ün belli başlı bölgelerinde özellikle tarihi çarşı ve çevresinde tek merkezli bir bölgeyi tercih etmekte ve kullanmaktadırlar. Yapılan analizlerden çıkan sonuçlara dayanarak Kadıköy merkezi üzerindeki baskıların giderilmesi ve yeni bir çekim alanı oluşturarak yaya hareketliliğinin kent bütününe yayılması adına, yayaların çokça tercih etmediği Yeldeğirmeni ve Haydarpaşa Bölgesinin yerel sistem ile bütünleştirilmesi amacıyla için bazı alt eylem projeleri düşünülmüştür. Potansiyel alan olarak özellikle Haydarpaşa Tren İstasyonu ve Yeldeğirmeni bölgesi düşünülmüştür. Çünkü özellikle 2010 yıllarından önce uğranılmayan ve nitekim yapılmış olan analizlerde de hala daha entegrasyonu düşük olan Yeldeğirmeni bölgesi 2011 yılında Kadıköy Belediyesi ve ÇEKÜL tarafından bir canlandırma projesine tabi tutulmuştur (Şekil 23).

\begin{tabular}{|c|c|c|c|}
\hline & İhtiyaç/Yöntem & Potansiyel Alan & \\
\hline 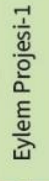 & $\begin{array}{l}\text { *Mahallelinin ve İstanbullunun } \\
\text { kullanabileceği aktif yeşil alanlar oluşturmak } \\
\text { *Yeniden işlevlendirmeler ile mahalleye } \\
\text { kültür, turizm ve hizmet alanları } \\
\text { kazandırmak. }\end{array}$ & $\begin{array}{l}\text { *Haydarpaşa tren garının açık } \\
\text { alanları ve eski TCDD yapıları } \\
\text { ile eski et balık kurumu binası. }\end{array}$ & $\begin{array}{l}\text { Eylem Projesi-1: Aktif Yeşil } \\
\text { Alan, Kültür, Turizm ve Hizmet } \\
\text { Alanları Oluşturulmasıyla Bir } \\
\text { Çekim Noktası Yaratmak ve } \\
\text { Yaşam Kalitesini Yükseltmek }\end{array}$ \\
\hline 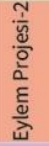 & $\begin{array}{l}\text { `Trafik durultma yöntemi ve paylaşımlı yol } \\
\text { tasanmlarıyla (bölgesel çözümlerle), trafik } \\
\text { vanalarıyla kavşak ve caddeleri düzenlemek. }\end{array}$ & $\begin{array}{l}\text { *Rıhtım Caddesi, Org. Şahap } \\
\text { Gürler Caddesi, Toplu taşıma } \\
\text { peronları. }\end{array}$ & $\begin{array}{l}\text { Eylem Projesi-2: Yaya-Taşıt } \\
\text { Karşılaşmasını } \\
\text { Güvenli Kılmak ve Ulaşım }\end{array}$ \\
\hline 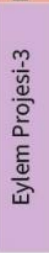 & $\begin{array}{l}\text { *Eski yapılara işlev verilerek, } \\
\text { sanatsal faaliyetler desteklenerek ve gezi } \\
\text { rotaları oluşturularak kentsel mekanda } \\
\text { akışı yeniden yönlendirebilecek aktivite } \\
\text { alanlarını yaratmak. (Aynı zamanda kent } \\
\text { ile deniz arasındaki ilişkiyi güçlendirecek } \\
\text { akışları da tasarlamak.) }\end{array}$ & $\begin{array}{l}\text { *Kentin kuzey ve } \\
\text { kuzeydoğusundaki tarihi yapılar, } \\
\text { kentsel boşluklar, atıl alanlar } \\
\text { ve sağır cepheler ile sahildeki } \\
\text { dolgu alanları. }\end{array}$ & $\begin{array}{l}\text { Eylem Projesi-3: Mahalle } \\
\text { Içindeki Bütünleşik Olmayan } \\
\text { Alanları Bütünleştirmek ve } \\
\text { Kentin Sahille İlişkisini Güç- } \\
\text { lendirmek }\end{array}$ \\
\hline
\end{tabular}

Şekil 23. Öneri eylem şeması

Potansiyel alan olarak düşünülen Haydarpaşa Tren İstasyonu ve Yeldeğirmeni'nin kuzeyini içine alan bölgeye yönelik bir tasarım şeması da önerilmiştir. Yeldeğirmeni'nin güçlü ızgara dokusunun devam ettirilerek yerel sistemdeki bütünleşmenin artırılması önerilmiştir. Onun dışında mekânsal kalitenin iyileştirilebilmesi adına yeşil bağlantıların kurulması ve yaya bağlantılarının planlanması önerilmiştir. Trafikte durultmaya gidilerek ve paylaşımlı yol tasarımlarıyla da yayaya daha çok alan kazandırılması önerilmiştir (Şekil 24). 

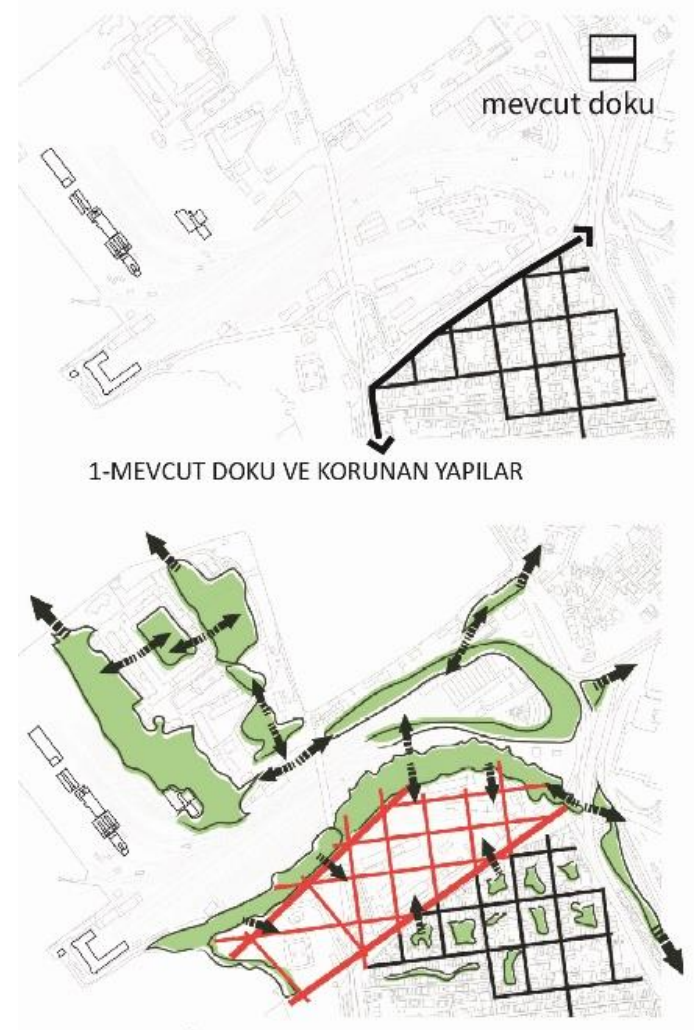

3-YEŞIL BAGLANTILARIN KURULMASI

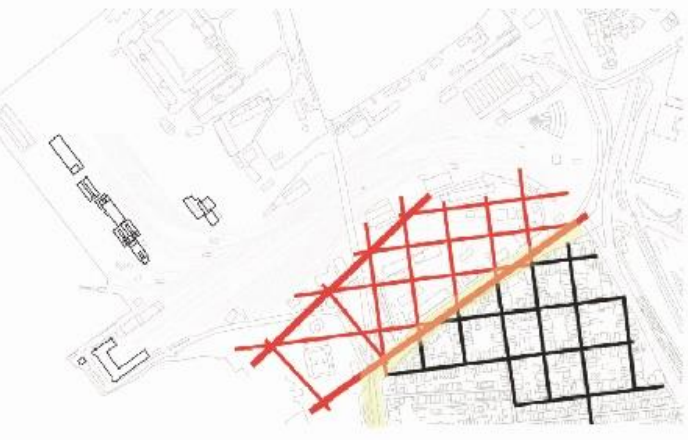

2-IZGARA DOKUNUN DEVAM ETTIRILMESi

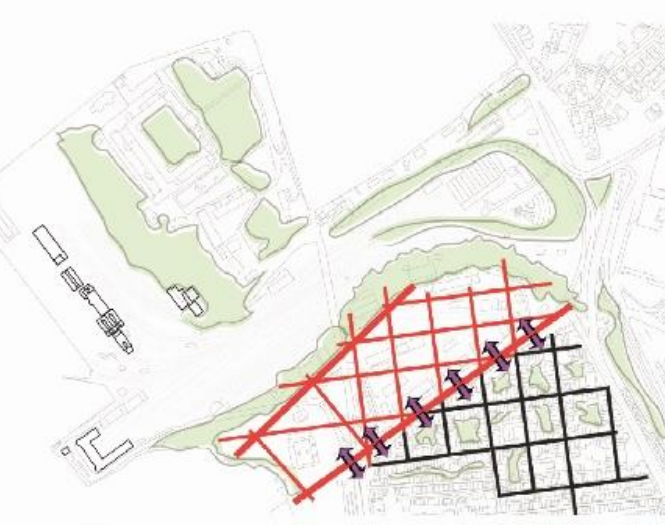

4-YAYA BAĞLANTILARININ KURULMASI VE TRAFIK DURULTMA

Şekil 24. Mekânsal kaliteyi arttırmada yönlendirici aksların önerisi

\section{Teşekkür ve Bilgi Notu}

Bu makale, Mimar Sinan Güzel Sanatlar Üniversitesi Mimarlık Fakültesi Şehir ve Bölge Planlama Bölümü'nde Doç. Dr. Müge Özkan Özbek yürütücülüğünde Ömer Alemdar tarafından Bitirme Ödevi olarak hazırlanmış olan ve "Bitirme Ödevi Projesi Yarışmasında" mansiyon ödülü alan ödevden üretilmiştir. Makalede, ulusal ve uluslararası araştırma ve yayın etiğine uyulmuştur. Çalışmada etik kurul izni gerekmemiştir.

\section{Kaynaklar}

Akbulut, M.R. (2004). Kentsel Tarih Araştırmalarında Bilgi Teknolojilerinin Kullanımıyla Yeni Bir Yöntem Geliştirilmesi (Kentsel Dönüşümde Kaos Kuramı ve Kadıköy-i̇stanbul Örneği), Mimar Sinan Güzel Sanatlar Üniversitesi Fen Bilimleri Enstitüsü, Doktora Tezi, İstanbul.

Al Sayed, K. (2018). Space Syntax Methodology, Bartlett School of Architecture, UCL.

Atılgan, A. (2017a). Kadıköy İskelesi [Blog yazısı]. Erişim adresi: http://atilganblog.blogspot.com/2017/02/

Atılgan, A. (2017b). Kadıköy Hal Binası Erişim Tarihi: 02.12.2018 http://www.mimdap.org/?p=197524. Kadıköy Hal Binası / Arif Atılgan.

Data Mining Geovisualation Research. (2017). Erişim tarihi: 28.04.2019. http://bitsnbricks.com/location-mining/. Location Mining in Kadikoy.

Emo, B. (2014). Real-World Wayfinding Experiments, University College London, Doctoral Thesis, London.

Gür, B. (2006). Yenileşme ve Kentsel Sit Alanlarında Uygulamalar-Kadıköy Tarihi Çarşı Sit Alanı Örneği, Mimar Sinan Güzel Sanatlar Üniversitesi Fen Bilimleri Enstitüsü, Yüksek Lisans Tezi, İstanbul.

Gür, B. (2018). Kadıköy İskelesi ve Çevresinin Tarihsel Süreç İçerisindeki Değişimi Üzerine Bir İnceleme, Mimar Sinan Güzel Sanatlar Üniversitesi Mimarlık Fakültesi Şehir ve Bölge Planlama Bölümü, Lisans Bitirme Ödevi, İstanbul. 
Hillier, B., Hanson, J. Peponis, J. ve Hudson, J. (1983). Space Syntax A Different Urban Perspective, AJ.

Hilliler B. ve Hanson, J. (1984). Social Logic of Space, Cambridge University Press, London.

Jansen, P., Heil, M. ve Schmid, J. (2007). Wayfinding Behavior and Spatial Knowledge of Adults and Children in a Virtual Environment: The Role of the Environmental, Heinrich-Heine-Universität Düsseldorf, Germany.

Kentvedemiryolu. (2011). Erişim Tarihi: 20.11.2018. http://kentvedemiryolu.com/yali-garimizhaydarpasa/.Yalı Garımız Haydarpaşa.

Kubilay, A. Y. (2010). İstanbul Haritaları 1422-1922. İstanbul: Denizler.

Özkan Özbek, M. (2007). Fizik Mekan Kurgularının Sosyal ilişkiler Üzerinden Arnavutköy Yerleşimi Bütününde Mekan Dizimi (Space Syntax) Yöntemi İle İncelenmesi, Mimar Sinan Güzel Sanatlar Üniversitesi Fen Bilimleri Enstitüsü, Doktora Tezi, İstanbul.

Özyılmaz, P. (2009). Kentsel Açık Alan Tasarımlarının Değerlendirilmesi İçin Mekan Dizimi Yaklaşımı, Gebze Yüksek Teknoloji Enstitüsü Mühendislik ve Fen Bilimleri Enstitüsü, Yüksek Lisans Tezi, Kocaeli.

$\begin{array}{llll}\text { Pingudumuzayede } & \text { (2018), } & \text { Erişim } & \text { Tarihi: }\end{array}$ https://www.pingudumuzayede.com/Images/Shop/9/Product/2357/17. jpg. Haydarpaşa Tren İstasyonu.

Sebuhyan, L. (2018, 26 Ekim). Mimari Yapıların Tarihçesi [Blog yazısı]. Erişim adresi: http://loransebuhyan.com/wp-content/uploads/2016/05/haydarpasa-tren-istasyonu-gari-11024x686.jpg. Haydarpaşa Tren İstasyonu.

Şendur, S. (2010). Kadıköy-Yeldeğirmeni Semti Mimarisinin Tipomorfoloji Yöntemiyle İncelenmesi. Yıldız Teknik Üniversitesi Fen Bilimleri Enstitüsü, Yüksek Lisans Tezi, İstanbul.

Taşçı, H. (2014). Bir Hayat Tarzı Olarak Şehir, Mekan, Meydan, İstanbul: Kaknüs Yayınevi.

Vaughan, L. ve Hillier, B. (2007). The Spatial of Urban Segragation, Space Syntax Articles. Bartlett School of Graduate Studies, UCL, London. 